
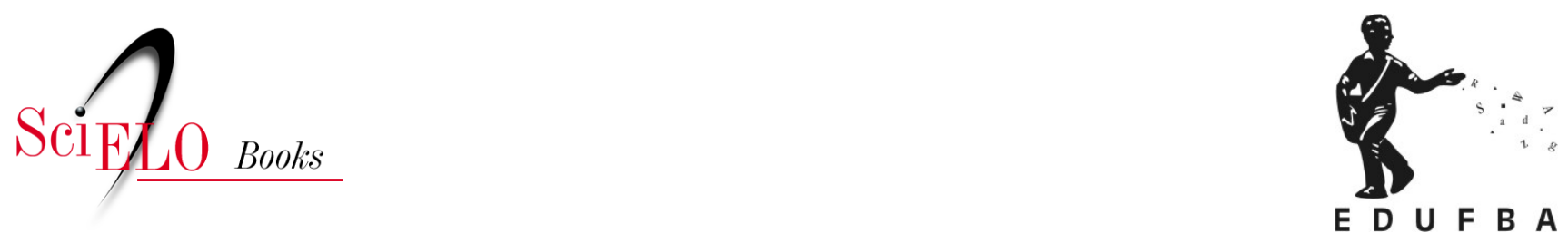

\title{
Modernização e reestruturação do modelo industrial de serviços postais da ECT
}

\author{
Tadeu Gomes Teixeira
}

TEIXEIRA, T.G. Modernização e reestruturação do modelo industrial de serviços postais da ECT. In: Os Correios e as políticas governamentais: mudanças e permanências [online]. Salvador: EDUFBA, 2016, pp. 105-177. ISBN: 978-85-232-2025-9. https://doi.org/10.7476/9788523220259.0006.

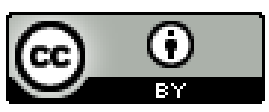

All the contents of this work, except where otherwise noted, is licensed under a Creative Commons Attribution 4.0 International license.

Todo o conteúdo deste trabalho, exceto quando houver ressalva, é publicado sob a licença Creative Commons Atribição $\underline{4.0}$. 

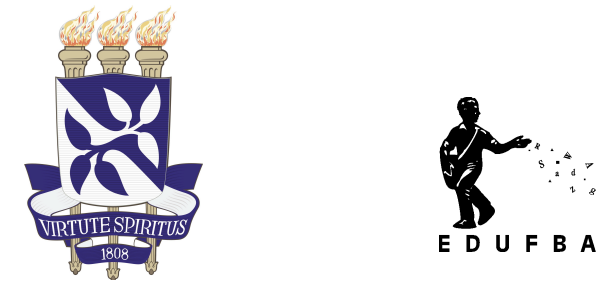

\section{UNIVERSIDADE FEDERAL DA BAHIA}

Editora da Universidade Federal da Bahia - EDUFBA

\section{Att. Scielo}

\section{ERRATA}

Informamos sobre o erro localizado no livro "Os Correios e as Políticas Governamentais: mudanças e permanências":

No capítulo Modernização e reestruturação do modelo industrial de serviços postais da ECT, do livro Os Correios e as Políticas Governamentais: mudanças e permanências, na página 152 onde se lia:

"Figura 15"

leia-se:

"Figura 6"

No capítulo Gestão do trabalho nos Correios, do livro Os Correios e as Políticas Governamentais: mudanças e permanências, na página 207 onde se lia:

"Figura 22"

leia-se:

"Figura 10" 


\section{Modernização e reestruturação do modelo industrial de serviços postais da ECT}

As transformações pelas quais passam os sistemas de correios no Brasil e no mundo não têm se restringido aos aspectos institucionais e organizacionais. Tais transformações foram acompanhadas também, e de maneira indissociável, de reestruturações nos processos de trabalho e na organização das atividades operacionais. A busca pela flexibilidade e eficiência aliada a novas ferramentas de gestão e ao desenvolvimento da microeletrônica e das tecnologias informacionais têm proporcionado significativos impactos na organização dos processos de trabalho dos sistemas postais.

Diante disso, o propósito deste capítulo é analisar os processos de modernização e reestruturação da área operacional dos Correios entre 1994 e 2011. Por atividades operacionais, refere-se aqui aos processos de captação de objetos postais, triagem (separação conforme local de destino) e distribuição domiciliária aos destinatários.

Para prestação dos serviços postais, a ECT subordina as suas atividades-fim - no âmbito nacional - à Vice-Presidência de Operações e às Gerências dos Centros de Tratamento de Cartas e Encomendas (GCTCE) de cada diretoria regional.

Cada atividade operacional é realizada por unidades operacionais específicas, como as Agências de Correios (ACs), os Centros de Tratamento de Cartas e Encomendas (CTCEs) e Centros de Distribuição Domiciliária (CDDs). No quadro 5, a seguir, visualiza-se o funcionamento sistêmico e interligado das atividades operacionais na ECT: 
QUADRO 5 - VISÃO SISTÊMICA DO PROCESSO OPERACIONAL NA ECT

\begin{tabular}{|c|c|c|c|c|}
\hline CAPTAÇÃO & & TRATAMENTO & & DISTRIBUIÇÃO \\
\hline $\begin{array}{l}\text { UNIDADES DE } \\
\text { CAPTAÇÃO }\end{array}$ & $\rightarrow$ & $\begin{array}{l}\text { UNIDADES DE } \\
\text { TRATAMENTO }\end{array}$ & $\rightarrow$ & $\begin{array}{l}\text { UNIDADES DE } \\
\text { DISTRIBUIÇÃO POSTAL }\end{array}$ \\
\hline $\begin{array}{l}\text { Agência } \\
\text { Internet } \\
\text { Caixa de Coleta } \\
\text { Outras unidades } \\
\text { (empresa, etc.) }\end{array}$ & Transporte & $\begin{array}{l}\text { CTC } \\
\text { CTE } \\
\text { CTCE }\end{array}$ & Transporte & $\begin{array}{l}\text { CEE } \\
\text { CDD }\end{array}$ \\
\hline
\end{tabular}

Fonte: Adaptado da ECT (2005, p. 18)

Nas unidades de captação, como as agências de atendimento, os trabalhadores são nomeados atendentes comerciais. Nas unidades de tratamento como os Centros de Tratamento de Encomendas e Cartas, trabalham os operadores de triagem e transbordo (OTTs), enquanto os carteiros desempenham suas atividades a partir dos Centros de Distribuição Domiciliária (CDDs) ou Centros de Entrega de Encomendas (CEEs).

De acordo com o Código Brasileiro de Ocupações (CBO) (2002), os carteiros e operadores de triagem e transbordo

[...] recebem e expedem cargas, malas e malotes e objetos de serviços de correio. Coletam, ordenam, conferem, fazem triagem e entregam cargas e objetos tais como: encomendas, cartas, caixas, malotes e contêineres. Prestam contas dos objetos coletados e entregues. Pesquisam e rastreiam objetos. Prestam informações e participam de disseminação de campanhas públicas. Também fazem parte desta família ocupacional os trabalhadores similares que atuam em empresas de encomendas expressas (courier).

A execução das atividades de trabalho, portanto, é similar. A diferença está, principalmente, no local de atividade profissional, pois o operador de triagem e transbordo realiza os procedimentos para encaminhamento dos objetos postais, enquanto os carteiros os distribuem.

Assim, a discussão apresentada neste capítulo versa sobre o fluxo do processo de trabalho postal: atendimento, tratamento/triagem e distribuição. Todavia, uma análise mais acurada é realizada nos Centros de Distribuição Domiciliária, pela importância estratégica dessas unidades e pela inexistência de estudos sociológicos sobre eles.

Na primeira parte do capítulo, discute-se a lógica dos métodos de gestão acionados pelos Correios para reestruturar os processos operacionais. 
Em seguida, abordam-se as estratégias delineadas de modernização operacional e como o processo de reestruturação foi realizado de forma indireta: pela disseminação de conceitos de gestão. Na sequência são discutidas as transformações das agências de atendimento, dos Centros de Tratamento de Cartas e Encomendas e, por fim, a lógica de gestão e as relações de trabalho nos Centros de Distribuição Domiciliária.

\section{"INDÚSTRIA DE SERVIÇOS POSTAIS": A LÓGICA DA GESTÃO OPERACIONAL}

Mesmo sem muito consenso acerca das características dos métodos de gestão que acompanham os processos de reestruturação - como o "toyotismo" -, como ressaltam Coriat (1994), Gounet (1999), Castells (2005) e Leite (2003), a nova lógica produtiva adotada pelas empresas apresenta como principais características os seguintes aspectos: a) a substituição da produção em massa padronizada por uma produção flexível direcionada aos interesses dos mercados, com imposição de flexibilidade aos processos produtivos; b) a busca constante pela melhoria do processo produtivo, incorporando o saber do trabalhador à produção; e c) a substituição de grandes empresas por empresas "enxutas", que focalizam a produção em partes específicas do processo produtivo.

A reestruturação produtiva, assim, abarca transformações que englobam

[...] 1) inovações nos equipamentos e materiais; 2) a mudança na relação entre empresas (por um lado, fusões, joint venture, compartilhamento de projetos, etc., e por outro, externalização e horizontalização da empresa); 3) novos métodos de organização da produção (just in time, kanban, qualidade total, manutenção preventiva, etc.); 4) novos métodos de organização do trabalho (trabalho em grupo, polivalência, etc.); e 5) inovações na gestão do trabalho (adoção de métodos 'participativos' e de envolvimento do trabalhador com a empresa). (SALERNO, 1992 apud KREIN, 2007, p.12)

O processo de reestruturação produtiva, que se acentuou no Brasil durante a década de 1990, foi acompanhado por uma reorganização do trabalho, das práticas e tecnologias de gestão da produção em busca de 
maior lucratividade e "melhorias" nos processos produtivos, cujos resultados apresentaram, quase sempre, uma maior intensificação e precarização do trabalho. (ALVES, 2000; LEITE, 1997)

No caso brasileiro, Gitahy (2000) identificou em diversas pesquisas processos de reestruturação a partir do novo paradigma produtivo calcado na flexibilidade. No mesmo sentido, Humphrey (1993) aponta para um "just in time taylorizado" nos processos produtivos das empresas que passaram por mudanças e adotaram os métodos japoneses, porque as práticas de gestão da produção utilizadas, da mesma forma que o taylorismo, não demandariam um maior envolvimento e participação dos trabalhadores, aumentando a coerção e pressão como resultado da exigência de polivalência e multifuncionalidade. Dessa forma, a versão "abrasileirada" do toyotismo, como afirma Salerno (1993), continua com uma divisão rígida do trabalho e uma prescrição rígida das tarefas, além de não possibilitar, como defendem os pós-tayloristas, uma autonomia aos trabalhadores no processo de trabalho.

Isso aponta, portanto, para um processo de mudanças na organização do trabalho que não é unívoco, por comportar especificidades conforme o setor estudado e as estratégias de gestão do trabalho no contexto da reestruturação das atividades produtivas, conforme observa Leite (2003). Assim, antes de tomar uma posição a priori, é importante acompanhar a posição de Linhart (2007), ou seja, "sair de um debate tão dividido e globalizante e se fixar na tarefa [...] de analisar as mudanças tais como se manifestam no interior das empresas, sem procurar sistematicamente estatuir o modelo que elas ilustram.” (LINHART, 2007, p. 30)

Ao estudar os Correios, portanto, é preciso analisar a organização do trabalho considerando a sua especificidade: trata-se de uma empresa prestadora de serviços. As atividades dos trabalhadores e a organização do trabalho na estatal precisam ser analisadas, ao seguir o argumento de Linhart (2007), a partir das especificidades dos serviços prestados.

Ao analisar o setor terciário, principalmente aspectos relacionados ao emprego, à produtividade e à avaliação, Gadrey (2001) mostra como o setor cresceu ao longo da segunda metade do século XX tanto nos países centrais do capitalismo quanto em países "emergentes" como o Brasil. O 
aumento significativo desse setor econômico suscita, segundo o autor, indagações e questionamentos relacionados à própria categoria que define as atividades como pertencentes às atividades terciárias.

Em decorrência disso, Gadrey (2001) trabalha com dois grupos de atividades terciárias: um grupo em que há uma diminuição dos empregos, composto pelas telecomunicações, transporte, bancos, seguros e correios; e um segundo grupo em que há uma expansão do emprego, não só nos países centrais do capitalismo, mas também nos periféricos, como os serviços de saúde, educação, turismo, serviço social etc.

Gadrey (2001) destaca o fato de as atividades terciárias em expansão apresentarem relações interpessoais, isto é, relacionamento direto entre sujeitos, interação verbal, troca de informações etc., o que caracteriza, especificamente, relações de serviço, como no caso dos serviços prestados por profissionais liberais que exigem um contato direto entre pessoas. No caso de atividades em que não há essa relação de serviço, pondera o autor, há uma tendência maior em introduzir processos que padronizem as atividades e "mecanizem" as operações, podendo mesmo ocorrer uma substituição do trabalho vivo por uma maior composição orgânica do capital, isto é, pelo emprego maior da automação. (GADREY, 2001)

É a partir disso que a produção industrial de serviço deve ser analisada. De acordo com Zarifian (2001), o setor industrial e o setor de serviços possuem convergências em seus processos, já que as atividades industriais têm oferecido, juntamente com os produtos desenvolvidos em seu interior, diversos serviços, como assistência técnica, seguro extra, etc. Ao mesmo tempo, as atividades consideradas de serviço estão a ser realizadas com diretrizes provenientes do mundo industrial. Dessa forma, a produção industrial de serviço deve ser conceituada, segundo Zarifian (2001, p. 69), como "uma produção que incorpora, nas suas tecnologias, na sua organização social, nos seus objetivos de eficiência, princípios semelhantes aos que são desenvolvidos na grande indústria e que os aplica, modificando-os, na produção de serviço".

Sendo assim, a dicotomia entre empresas industriais e de serviços teria pouca capacidade explicativa sobre as dinâmicas do trabalho e da produção nas empresas contemporâneas (SALERNO, 2001), sobretudo 
quando as corporações que seriam consideradas prestadoras de serviços organizam o trabalho com princípios desenvolvidos na indústria. Diante disso, o conceito de produção industrial de serviço, tal como o define Zarifian (2001), apresenta uma possibilidade de compreensão da dinâmica do trabalho no âmbito da ECT, que seria uma empresa de serviço, mas que apresenta na organização de seu processo de trabalho princípios e diretrizes formuladas e desenvolvidas na indústria.

É importante destacar que mesmo antes das discussões sobre reestruturação produtiva e sobre a incorporação de novas tecnologias e ferramentas na organização e prestação de serviços, atividades que seriam consideradas terciárias já utilizavam, em sua organização do trabalho, princípios típicos da produção industrial. É por isso que Braverman (1987) analisa o setor de serviços, ou o trabalho em "escritórios", como sendo caracterizado por uma racionalização que faz uso, tanto quanto as indústrias, de princípios e técnicas da administração científica.

Pesquisas realizadas no Brasil indicam, já há pelo menos duas décadas, a transposição de práticas e métodos industriais para as atividades terciárias, como os trabalhos de Zamberlan e Salerno (1983) acerca da organização do trabalho em bancos, e também os de Grun (1986), que analisou as especificidades do trabalho bancário nos moldes de uma racionalização taylorista e fordista. Mais recentemente, trabalhos como os de Segnini (2001) apontam para o processo de produção industrial de serviços também no setor de telecomunicações, mais precisamente na área de telemarketing, principalmente a partir da utilização de técnicas de automação e mecanização de suas atividades, aspecto que também é discutido por Braga (2006), que aponta, principalmente, para a degradação do trabalho dos teleoperadores a partir da taylorização desse serviço.

Em se tratando da ECT, a lógica industrial nos serviços torna-se evidente quando se observa que a reestruturação iniciada em 1994 tinha dentre seus objetivos introduzir na empresa a "utilização de ferramentas e conceitos ligados ao sistema Toyota de produção”. (ECT, 2005, p. 06) Para os responsáveis pela reestruturação, não há dúvidas de que, "para melhor compreender as transformações que deram origem à concepção atual [de 
produção]", é preciso entender que a "ECT incorpora ao seu modelo a ideia de indústria de serviços.” (ECT, 2005, p. 15, grifo nosso)

Ao tratar desse processo, é imprescindível considerar que a reestruturação nos Correios e a adoção de novas estratégias de gestão foram realizadas com base em dois pressupostos:

[...] primeiro, as similitudes entre a produção industrial, conhecida como produção em massa, e a produção de serviços em larga escala, como é feita pelos Correios, determinaram uma busca por novas tecnologias que permitissem a conjugação de aspectos como maior flexibilização, melhor qualidade e produtividade [...];

segundo, o reconhecimento da necessidade de se estabelecer uma condição de trabalho humano capaz de propiciar e despertar o interesse pela racionalização dos processos, pela eliminação de desperdícios [...]. (ECT, 2005, p. 17)

Diante disso, os processos de trabalho na ECT foram reorganizados a fim de ajustar as duas lógicas - a industrial e a de serviços -, tanto no sentido de alinhá-las quanto na racionalização e sistematização, "otimização" e padronização dos processos de trabalho.

Nesse cenário, pode-se indicar que a relação de serviço estabelecida a partir dos Correios é de tipo peculiar, já que em dois momentos distintos ocorre a inter-relação com o cliente: na captação e na distribuição dos objetos postais. $O$ atendimento de suas expectativas, no sentido de prestação de um serviço e de relação de serviço, como analisa Gadrey (2001), coloca em perspectiva um processo que desencadeia nas unidades operacionais uma dinâmica produtiva presente na indústria, como as entradas, processamentos e saídas de produtos e mercadorias.

No caso dos Correios, esse macroprocesso identifica as entradas com as postagens de objetos postais - de quaisquer tipos - nas agências de Correios. Apresenta o processamento nas unidades de tratamento, como os Centros de Triagem, onde são separados conforme a localidade de destino, e seguem, como produto final a ser entregue aos clientes, pelos Centros de Distribuição. Assim, tanto o atendimento ao cliente, o tratamento dos objetos postais e a sua distribuição são vistos como processos de um mesmo "sistema" produtivo, amplo, que engloba uma relação de serviço com 
os clientes e possui, como processamento direto, ferramentas e técnicas específicas em cada uma dessas etapas, no sentido ajustado de uma produção industrial de serviço.

Assim, a reestruturação operacional implementada na ECT na década de 1990 com o objetivo de "modernizar" as práticas de gestão incorporou a lógica produtiva industrial de forma planejada na organização do trabalho nos processos operacionais, como tem sido uma constante nos processos de reestruturação produtiva. (SALERNO, 2001)

\section{DIRETRIZES PARA MODERNIZAÇÃO E REESTRUTURAÇÃO OPERACIONAL DOS CORREIOS (1994-2011)}

As estratégias para reestruturação e modernização dos processos operacionais na ECT foram traçadas para abarcar, a partir do governo Fernando Henrique Cardoso, o processo operacional sistêmico, isto é, as três áreas estratégicas para o fluxo operacional.

Os planos para reformulação operacional foram apresentados no Programa de Recuperação e Ampliação do Sistema de Telecomunicações e do Sistema Postal (PASTE) em 1997, embora na primeira versão do documento, de 1995, já estivessem presentes. A previsão do governo FHC era investir mais de quatro bilhões de reais na modernização e reestruturação da ECT entre 1996 e 2003 em projetos de automação de agências, sistemas informatizados de gestão gerencial e de atendimento, além da mecanização e automação dos processos de triagem. Seguindo a lógica de mercado prevista para ser implantada com a reforma institucional, o governo FHC previa, portanto, uma "modernização" e reestruturação operacional na estatal para adequá-la ao "ambiente concorrencial", isto é, a liberalização postal.

O início dos processos de modernização nos Correios remonta a 1995, quando o governo de FHC apresentou no PASTE o interesse em acompanhar as transformações postais internacionais. O objetivo do governo federal era aprofundar a implantação da lógica empresarial na estatal. Isso fica claro quando o governo afirma no PASTE, por exemplo, estar atento às "virtudes" dos instrumentos gerenciais implantados em 
outros países. Nesse sentido, as primeiras ações para o setor postal foram para a sua reestruturação.

A perspectiva de mudança postal durante o governo FHC incluía os seguintes aspectos:

- Preservação do diferencial da rede de atendimento, ajustando-a constantemente a maiores níveis de conforto para o cliente através da melhoria dos processos de atendimento, expansão do número de pontos de acesso e adoção de novas tecnologias;

- Formação de alianças, associações, acordos operacionais e comerciais com companhias governamentais e privadas, clientes, fornecedores e, até mesmo, concorrentes;

- Re-desenvolvimento dos seus quadros profissionais;

- Investimentos em automação dos processos de produção;

- Obtenção de ganhos de produtividade através da revisão dos processos operacionais tradicionais dos Correios;

- Modernização da gestão no sentido de se tornarem organismos ágeis e orientados ao mercado; e,

- Redução de custo de operação e, por conseqüência, dos preços e tarifas dos serviços. (BRASIL, 1997, p. 24-25)

Com esses objetivos, o governo de Fernando Henrique Cardoso buscou implementar, dentre outras premissas para a adoção de padrões de qualidade e utilização de tecnologias nos processos de inovação, as seguintes ações:

- Modernização da rede de atendimento, priorizando as capitais e grandes cidades, e expansão do atendimento, em um primeiro momento, a todos os municípios e, posteriormente, a todas as localidades que apresentem viabilidade de operacionalização;

- Implantação de programa integrado de automação, mecanização e informatização das etapas do fluxo operacional, buscando o aumento da produtividade e da segurança na prestação dos serviços;

- Reformulação da logística postal para torná-la consistente com as novas tecnologias de automação, transporte e informática; 
- Desenvolvimento profissional e pessoal de seus recursos humanos;

- Modernização da gestão empresarial da ECT através de posturas, procedimentos e sistemas que a tornem uma organização orientada ao mercado;

- Formulação de um novo modelo institucional para o setor postal brasileiro. (BRASIL, 1997, p. 90)

Diante dessas estratégias, o governo FHC previa uma reestruturação sistêmica com transformações nas políticas de gestão do trabalho, nos métodos de organização do trabalho em unidades operacionais e na rede de atendimento, investimentos na mecanização e automação da triagem, melhorias e aperfeiçoamento da logística de transporte e distribuição postal, e tudo isso dentro de um contexto de reforma institucional com uma empresa mais alinhada aos princípios de mercado e preparada para atuar em um contexto de liberalização do mercado postal.

É preciso destacar que a reestruturação tomou forma a partir do desenvolvimento de um projeto pensado para impactar todos os meandros do processo operacional, instrumentalizando os gestores com novos métodos e estratégias de gestão para aplicação nos processos de trabalho. Trata-se do projeto "Gestão da Produtividade Aplicada aos Correios" (GPAC), apresentado a seguir.

\section{Formulação e desenvolvimento do Projeto GPAC}

Com o objetivo de reestruturar os métodos de gestão de suas unidades operacionais, a ECT firmou contrato com a Universidade Federal do Rio Grande do Sul (UFRGS) para implantar, a partir de 1995, um projeto de reformulação de seus métodos de gestão operacional. A partir desse contrato foi criado o projeto "Gestão da Produtividade Aplicada aos Correios" (GPAC), que ficou encarregado de diagnosticar, elaborar e propor as melhorias necessárias aos processos de trabalho, bem como a maneira de realizá-las. Professores vinculados à universidade, predominantemente da área de engenharia da produção, elaboraram um diagnóstico e formularam as diretrizes que possibilitaram a reestruturação das atividades de trabalho com o intuito de aumentar a qualidade e a produtividade. Por 
parte da ECT foram designados técnicos especializados para, de forma articulada, elaborarem as intervenções nos processos de trabalho.

As estratégias delineadas no projeto GPAC não previam uma intervenção direta nos processos de trabalho: inicialmente, além do diagnóstico, objetivou-se disseminar conhecimentos, técnicas e ferramentas de administração da produção, principalmente as relacionadas ao toyotismo, para todas as áreas dos Correios, em todas as Diretorias Regionais e na Administração Central, "para que se obtenha melhoria contínua dos processos e o consequente aumento da produtividade." (ECT, 2005, p. 355) A partir disso seriam planejadas intervenções nos processos de trabalho.

O projeto GPAC, instituído nos Correios por decisão integrada das Diretorias de Operações, Técnica e de Recursos Humanos, foi implantado em três etapas compostas por cursos de capacitação padronizados durante o período que se estende de 1994 a 1999.

A primeira etapa iniciou-se em 1995 com um curso de 40 horas, ministrado por professores da UFRGS versando sobre administração da produção. Foi ministrado para profissionais da ECT do Rio Grande do Sul. A partir dessa experiência, resultados práticos foram alcançados em várias Diretorias Regionais, o que motivou a continuidade e propagação do projeto. Esses resultados foram divulgados no primeiro Seminário Gestão da Produtividade Aplicada aos Correios, que se tornaria parte do projeto de reestruturação da empresa. A meta desse seminário era divulgar os resultados das experiências dos gestores que aplicaram os novos conhecimentos de gestão em suas unidades operacionais, mobilizando, com isso, os demais funcionários da empresa.

Diante disso, respaldados pela direção da ECT, foram organizados vários seminários que objetivavam tornar o projeto GPAC conhecido pelas Diretorias Regionais, pelos Diretores Adjuntos, Assessores, Gerentes de Área, Chefes de Regiões Operacionais, Subgerentes e demais funcionários. A estratégia da empresa era disseminar e tornar o projeto atraente para os funcionários, que poderiam se envolver com suas atividades para alcançar os resultados de melhoria da qualidade, da participação no mercado, na produtividade e na melhoria da entrega das correspondências. (ECT, 2005) 
Para que o projeto pudesse ser disseminado em todas as Diretorias com o mesmo formato e com o mesmo padrão, e ao mesmo tempo, foram formadas três turmas de multiplicadores do projeto: a primeira turma, com 24 alunos, formada por profissionais indicados pela ECT, que foi treinada em um curso de especialização e se tornou responsável por compartilhar os conhecimentos adquiridos com as lideranças operacionais (em torno de 1.600 funcionários); a formação, pelos 24 especialistas, de uma turma de 110 multiplicadores - responsáveis pela formação de supervisores operacionais (aproximadamente 3.360) nas Diretorias Regionais; por fim, a formação de cerca de 44.000 trabalhadores da área operacional - trabalhadores de execução - com conhecimentos referentes à sua área de trabalho. A figura 4 apresenta, esquematicamente, esse momento do projeto.

FIGURA 1 - NÍVEIS DE MULTIPLICADORES DO PROJETO GPAC

Professores da UFRGS e profissionais dos Correios

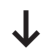

FASE I

Formação de 24 multiplicadores (em 360 h/a) para ministrar curso GPAC às 1.610 lideranças operacionais (40 h/a) no nível nacional.

\section{FASE III}

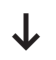

FASE II

Os 24 multiplicadores e profissionais da ECT formaram 110 multiplicadores (em $80 \mathrm{~h} / \mathrm{a}$ ) para ministrar curso GPAC aos 3.361 Supervisores de Operações (20h/a) nas suas Diretorias Regionais.

A equipe de multiplicadores (duplas) formou 670 profissionais (em $32 \mathrm{~h} / \mathrm{a}$ ), para ministrar o curso GPAC aos 44.000 empregados de cargos de nível básico que atuam na distribuição (8 h/a).

Fonte: Adaptado de ECT (2005, p. 358).

A segunda fase do projeto consistiu na elaboração, a partir da imersão dos professores em unidades operacionais, de relatórios acerca das condições do processo de trabalho na organização, apontando, a partir disso, as principais diretrizes para a formação e disseminação dos conhecimentos de gestão. Assim, formulou-se e padronizou-se o curso que seria oferecido aos funcionários da empresa. 
A partir da realização dos cursos de formação, cujos ensinamentos deveriam redundar em projetos para reformulação de práticas de gestão de operações, foram realizados seminários para apresentação dos projetos elaborados, sendo que os escolhidos seriam adotados nas unidades operacionais semelhantes. Nesse sentido, em 2000 foi realizado o principal seminário nacional de gestão da produtividade que proporcionou aos melhores projetos desenvolvidos o Prêmio Produtividade dos Correios.

Com isso, os trabalhos considerados mais adequados à realidade dos Correios e que cumpriram certos requisitos foram adotados, padronizados e disseminados nas unidades operacionais das diversas Diretorias Regionais. Dentre os requisitos cumpridos pelos projetos, destacam-se os seguintes:

[...] aplicabilidade (o trabalho poderá ser operacionalizado na unidade); possibilidade de implantação em outras unidades; eliminação de perdas; redução de custos; introdução de melhorias no processo (otimização e racionalização dos processos com ganho e qualidade); relação dos conceitos teóricos com a prática [...]. (ECT, 2005, p. 372-373)

O processo de disseminação de conhecimentos de administração da produção entre os trabalhadores da ECT, dentre os quais figuravam os princípios e técnicas do modelo toyotista, apresenta as mesmas características do processo de implantação dos princípios da administração científica na primeira metade do século XX no Brasil, quando houve uma ênfase na formação da mão de obra para torna-la disciplinada e adequada ao trabalho, processo que ocorreu antes da organização dos processos de trabalho de acordo com os princípios do taylorismo. (VARGAS, 1985)

No caso dos Correios, os esforços foram no sentido de "sensibilizar" a força de trabalho, tanto as lideranças da organização quanto os funcionários da área operacional, para a necessidade de reestruturar e implantar melhorias, que passavam pela adoção de novas técnicas de gestão, envolvendo a colaboração e participação de todos os funcionários, seja propondo intervenções, seja realizando o que foi estabelecido pelos gestores nas unidades operacionais. Assim, o primeiro momento, ainda de formulação e disseminação de novas tecnologias de gestão, envolveu e procurou 
convencer os funcionários da necessidade da reestruturação, ficando para um segundo momento a intervenção nos processos operacionais.

Assim, enquanto o taylorismo no Brasil foi implantado em pelo menos dois momentos - os princípios e as técnicas de gestão, respectivamente, na primeira e segunda metades do século XX -, o toyotismo na ECT o foi em menos de dez anos (1995 - 2005), pelo menos no que se refere à disseminação de seus princípios até as funções operacionais, por meio de técnicas e instrumentos de gestão.

Ao final do projeto GPAC, uma série de relatórios foi produzida, principalmente nas áreas em que o processo já apresentava alterações significativas, como nas áreas de captação, tratamento, transporte e distribuição. De acordo com a ECT (2005), o projeto GPAC a capacitou para melhor gerir, inclusive, as mudanças tecnológicas pelas quais passava, como a implantação do sistema de rastreamento eletrônico de objetos postais, a mecanização de centros de tratamento etc. Além disso, esses projetos foram integrados aos manuais da empresa, respaldando as ações dos gestores e normatizando as intervenções no processo de trabalho.

Os projetos de reestruturação das unidades operacionais foram sendo implantados e integrados à padronização e normatização da ECT, sendo, a partir disso, "a melhor maneira" de se realizar as atividades de trabalho, orientando, com isso, as tarefas dos supervisores operacionais e gerentes das unidades.

Na próxima seção, analisa-se como a lógica da modernização e da reestruturação foi acionada na gestão das agências de atendimento, processo que antecede, inclusive, o governo de Fernando Henrique Cardoso.

\section{A INFLUÊNCIA DA LÓGICA FLEXÍVEL: TERCEIRIZAÇÃO DAS AGÊNCIAS E REDE DE ATENDIMENTO}

As agências dos correios e a rede de atendimento postal são os integrantes mais visíveis da infraestrutura postal de um país. As agências de correios históricas evidenciam a importância simbólica dos sistemas postais em regiões rurais e distantes dos grandes centros porque foram, em algum momento, representantes dos Estados nacionais. Por isso, as 
transformações no setor postal, sobretudo na Europa, têm esbarrado em questões politicamente delicadas ao propor a introdução da lógica de mercado às agências. Nesse sentido, em países como Suécia e Noruega, onde o direito de voto pode ser exercido nas agências de correios, o fechamento de uma agência torna-se politicamente delicado pela possibilidade de ser interpretado pela população como um atentado à democracia. (ANDERLONI; PILLEY, 2002)

Apesar disso, desde o início das transformações postais a rede de atendimento na União Europeia tem buscado meios para aumentar a sua eficiência e lucratividade. Com isso, o fechamento, a adoção de franquias, a privatização, o licenciamento, etc., de agências têm sido uma tendência naquele continente, com o sistema postal de cada país implantando estratégias que considera mais eficazes, o que enseja uma multiplicidade de situações. (ANDERLONI; PILLEY, 2002)

No Brasil, a rede de atendimento da ECT é a porta de acesso de cidadãos e clientes aos Correios. A rede é formada por diferentes tipos de agências, próprias ou terceirizadas. Em 2011, a estatal dispunha de 22.763 atendentes comerciais nas agências próprias, isto é, $21 \%$ dos trabalhadores da empresa. Nas agências terceirizadas, a estimativa é de aproximadamente 20 mil trabalhadores desempenhando funções relacionadas ao serviço postal. (SENADO..., 2011)

A Portaria no. 384, de 2 de setembro de 2011, regulamenta a rede de atendimento dos Correios ao especificar os tipos e funções das agências. Pela portaria, a rede é formada por Agências de Correios (AC), Agências de Correios Comerciais (ACC), Agências Filatélicas (AF), Agências de Correios Franqueadas (AGF), Agências de Correios Comunitárias (AGC) e Postos de Venda de Produtos.

As diferentes agências existem em razão de estratégias diferenciadas da estatal para atender aos cidadãos e clientes. As Agências de Correios são unidades próprias da ECT, destinadas à venda e prestação de serviços próprios e para terceiros, bem como para atendimento aos clientes de segmentos comercialmente estratégicos.

As Agências Comunitárias são operadas mediante convênio para prestação de serviços básicos em localidades onde os serviços postais não se 
mostram economicamente viáveis; assim, trata-se de um atendimento em que predomina o interesse social.

As Agências Comerciais de Correios e as agências franqueadas são agências terceirizadas. A diferença básica entre os tipos de contrato de terceirização diz respeito ao tipo de produto que comercializam, sendo as agências franqueadas mais restritas na oferta de serviços.

Com essas informações é possível adiantar que ao analisar as estratégias e rumos da rede de atendimento da ECT, a partir da década de 1990, verifica-se uma gama de possibilidades comerciais relacionadas ao ambiente de atuação da ECT, com destaque para a tendência à terceirização associada à lógica de modernização.

O processo de terceirização das lojas de atendimento remonta ao final da década de 1980, quando, a despeito da ampliação da rede de serviços e de um significativo aumento da lucratividade nos primeiros anos da década de 1990, a ECT passou a alegar falta de recursos para investimento em sua modernização e ampliação da infraestrutura, sobretudo para instalação de novas agências de atendimento.

Para ampliar o número de agências rapidamente, a empresa adotou como estratégia gerencial o sistema de franquias. A primeira experiência foi realizada no Rio Grande do Sul em 1989. A partir de então, a experiência cresceu vertiginosamente. De acordo com Carvalho e Leite (1996), no plano estratégico da ECT em 1990 o sistema de franquias estava identificado como um setor essencial no processo de ampliação da rede postal. Compreende-se, assim, porque a ECT, já em dezembro de 1992, dispunha de 1.443 unidades de atendimento franqueadas, alcançando mais de 1.700 em 1993. Naquele ano, os Correios possuíam 5.237 agências próprias. Esses números são ainda mais reveladores ao se considerar que na década de 1980 foram abertas apenas 203 novas agências. (CARVALHO; LEITE, 1996)

Segundo Carvalho e Leite (1996), a rápida expansão da rede franqueada pode ser explicada pela imagem favorável que a ECT dispunha à época junto ao mercado, com histórico de credibilidade e marca favorável. Todavia, um elemento que contribuiu enormemente foi o baixo preço da franquia, fixado em torno de quatrocentos e quarenta dólares. 
Em 1993, a ECT interrompeu a concessão de franquias para reavaliar o sistema, embora tivesse o plano de atingir cerca de duas mil agências franqueadas em todo o Brasil. Este seria o ponto de saturação da rede. Os principais mercados de atuação das agências eram os estados de São Paulo, Rio de Janeiro e Brasília, que foram considerados saturados já em 1993.

Os contratos firmados pela ECT, no entanto, não passaram por um processo licitatório. Com a entrada em vigor da Lei das Licitações (Lei nº 8.666, de 1993), o Tribunal de Contas da União (TCU) determinou que a ECT abrisse processo licitatório para substituição das franquias anteriormente concedidas sem o devido processo legal. Desde então uma série de disputas e imbróglios judiciais tem perpassado o assunto. Em 1998, a Lei no. 9.648 estendeu o prazo da ECT para realização das licitações até 2002, renovando o prazo para continuidade das agências franqueadas.

No entanto, ainda em 2002 estavam em discussão no Congresso Nacional os parâmetros para um novo arranjo institucional para a reestruturação dos Correios. Com isso, mais uma vez o prazo foi estendido até 2007. Em 2008, a Lei no. 11.668 passou a regular e normatizar os instrumentos contratuais da ECT com as agências franqueadas. No entanto, enquanto a previsão para o término das licitações corria até 2010, o TCU detectou irregularidades nos editais - possivelmente viciados e direcionados - e determinou a suspensão das licitações. Com toda essa novela judicial, um novo prazo foi estabelecido para substituição dos contratos que são questionados judicialmente ou que não foram licitados: setembro de 2012.

Das agências fraqueadas, 227 tiveram o processo de licitação concluído, outros 504 contratos estão com as licitações em andamento, enquanto 519 processos de licitação foram suspensos por medidas judiciais. As agências franqueadas, portanto, agora contam com mais um prazo para se adequarem à Lei no $n^{\circ}$ 11.668/2008 e continuarem a operar, sobretudo se ajustando aos critérios de padronização e normas técnicas de gestão. Caso os prazos não fossem estendidos, a ECT precisaria investir pelo menos R 550 milhões em pessoal, equipamentos e instalações para assumir as agências franqueadas, o que levou o deputado Ricardo Berzoini (PT) a afirmar que "diante de tal desafio, parece claro que o mero cancelamento dos contratos de franquia é impraticável, o que torna indispensável sua 
prorrogação." (FRANQUIAS..., 2011) Esse cancelamento dos contratos passou a ser tratado pela mídia como um possível "apagão postal".

A terceirização das agências dos Correios é coerente com o processo de terceirização que passou a ser largamente utilizado pelas empresas brasileiras a partir da década de 1990, em busca de flexibilidade e redução de custos. No caso dos Correios, o que se observa é uma externalização das atividades de atendimento, ficando as agências terceirizadas - sob o sistema de franquias - responsáveis pelos encargos trabalhistas e por estabelecerem as condições de trabalho de seus funcionários.

A terceirização da rede de atendimento da ECT associou-se às estratégias de expansão do setor postal previstas pelo governo FHC e incorporadas ao PASTE. Nesse sentido, em 1997, em um balanço acerca dos impactos da primeira versão do PASTE, o Ministério das Comunicações informou que havia conseguido aumentar o número de municípios atendidos para 4.812 e a quantidade de agências e caixas de coletas em 8\%. (BRASIL, 1998)

Associado a esse processo, há indícios de que as concessões foram realizadas a partir de indicações políticas e, juntamente com isso, surgiu a suspeita de alterações nas titularidades ou alteração da composição societária entre proprietários de agências de maneira não oficial (o chamado "contrato de gaveta").

Diante disso, a Comissão Parlamentar Mista de Inquérito instaurada para apurar irregularidades nos Correios, a CPMI dos Correios, informa em seu relatório final que depois dos processos investigativos é possível afirmar que os indícios eram verdadeiros, isto é, que a inexistência de licitações para a concessão das agências franqueadas permitiu a distribuição de muitas franquias a partir de critérios políticos, bem como possibilitou, por meio de instrumentos legais precários, a propriedade de fachada das agências, impossibilitando em algumas situações a identificação dos verdadeiros donos.

Além disso, o processo de terceirização de agências foi prejudicial à ECT, como informa a CPMI dos Correios, já que muitos contratos de grandes usuários migraram das agências próprias da estatal para a rede terceirizada a partir de uma disputa comercial entre elas, favorecendo os particulares em detrimento do interesse público. (BRASIL, 2006) 
De acordo com a CPMI dos Correios, as irregularidades encontradas na ECT em si já seriam graves, mas se tornaram ainda piores ante a possibilidade de estarem associadas à lavagem de dinheiro e crimes contra a administração pública, como corrupção, tráfico de influência e prevaricação, além da evasão de divisas e sonegação fiscal. (BRASIL, 2006, p. 416)

Sendo assim, a Comissão Parlamentar de Inquérito endossou a recomendação à ECT acerca da necessidade de licitações e procedimentos administrativos que visassem resgatar os prejuízos tomados, como uma clara especificação acerca da atuação e forma de remuneração das agências franqueadas. Parte dessas ações ainda está em curso, como se observa no procedimento de licitação instaurado em dezembro de 2011 para ampliação da rede com mais de 800 novas lojas.

\section{Ações para modernização da rede de atendimento: a introdução de sistemas informatizados}

As ações para ampliação e modernização da rede de atendimento também contemplavam a implantação de sistemas automáticos e informáticos. Assim, a estatal brasileira acompanhava o processo de investimentos na modernização da infraestrutura tecnológica das agências de forma semelhante ao que estava em curso na Europa entre 1995 e 2002. (PLS RAMDOLL, 2002)

Os principais projetos na ECT, nesse sentido, foram investimentos na automação de agências, em guichês de autoatendimento, em sistemas eletrônicos de rastreamento de objetos postais e a utilização de sistemas informáticos nas redes de atendimento.

A maior parte desses projetos teve sua implantação a partir de 1997, embora já em 1996 alguns investimentos tenham sido realizados, como a implantação de sistemas automatizados para atendimento nas agências, com 478 unidades atendidas até então. (BRASIL, 199?)

Ainda em 1997 entrou em operação a rede corporativa CorreiosNet, instalando-se mais de 4.000 estações de trabalho e 252 serviços padronizados e informatizados no sistema. 
Com isso, a ECT passou a contar com o atendimento em suas lojas de uma rede corporativa informatizada capaz de possibilitar não só a utilização das tecnologias informacionais para atendimento aos clientes, mas também vislumbrar a implantação de outros serviços - como o rastreamento de objetos postais.

A informatização das agências possibilitou aumentar a eficiência dos serviços prestados, tornando-os "mais rápidos e seguros" de acordo com a empresa. Os dois primeiros sistemas implantados na rede de atendimento foram o SCADA (Sistema de Captação de Dados nas Agências) e o SAA (Sistema de Automação de Agências). A diferença entre eles está na plataforma tecnológica. Em outras palavras, o SCADA previa a instalação de microcomputadores, autenticadores, impressoras, leitores de códigos de barra, etc., "a fim de facilitar o trabalho de atendimento". Já o SAA era uma plataforma de atendimento onde se executavam tarefas de atendimento, controle financeiro, contábil, administrativo, logístico etc. Apesar de inicialmente previsto apenas para grandes agências, foi implantado posteriormente nas demais. Segundo a empresa, os funcionários aprovaram a implantação dos sistemas informáticos porque

[...] são treinados e aumentam sua qualificação profissional. Deixam de fazer rotinas manuais, como decorar ou pesquisar valor de tarifas, e fecham as contas do dia em menos da metade do tempo exigido anteriormente. 'Já peguei intimidade com os equipamentos', teria dito uma atendente comercial que antes gastava meia hora para fechar o caixa da agência no final do dia e que depois da implantação do sistema a mesma tarefa passou a ser realizada em dez minutos. 'Antes a gente pesava, olhava e conferia tudo. Agora não preciso quebrar a cabeça', diz. Com o SAA, basta digitar o CEP para que o preço do valor da encomenda ou correspondência seja registrado. (AUTOMAÇÃO..., 1999)

A maior mudança em termos de operação de sistemas informacionais, no entanto, ocorreria a partir de 2003 com a implantação em todas as agências, incluindo terceirizadas, até 2005, do Sistema de Automação da Rede de Agências (SARA), que substituiria o SCADA. Quando implantado, uma matéria do jornal corporativo Correios do Brasil explicou o que era e como funcionaria o novo sistema: 
[O sistema SARA] irá gerenciar as atividades comerciais e financeiras das agências, possibilitando a rápida implementação de novos serviços, a utilização de bases de dados centralizadas, a integração com os sistemas corporativos e o acompanhamento on-line das vendas, saldos e estoques, dentre outras facilidades.

O SARA é um aplicativo com base de dados centralizada que automatiza todas as posições de trabalho da agência, incluindo guichês, supervisor, caixa de retaguarda e gerente da unidade. O novo sistema, que utilizará a rede corporativa dos Correios, contempla 275 funcionalidades voltadas para o atendimento e gerenciamento das agências, que vão desde orientação sobre postagem de cartas até a verificação de contratos, possibilitando melhoria dos processos internos, precisão e credibilidade das informações.

Como funciona - Na tela inicial do SARA, é solicitada a matrícula e senha do atendente. A partir daí, estão disponíveis as informações do sistema. Com o SARA, é possível saber on-line a receita diária da agência, quantos selos foram vendidos ou quantos clientes estão sendo atendidos naquele instante. As DRs terão, inclusive, um controle da sazonalidade dos serviços. Poderão, por exemplo, detectar os horários de pico ou de menor demanda de cada agência, estando em condições de modificar as rotinas de atendimento. (TECNOLOGIA..., 2002)

O SARA é integrado ao sistema do Banco Postal, o que agrega à função de atendente comercial dos Correios a atividade de operador bancário. Em tal sistema é possível extrair informações gerenciais facilmente, além de controlar toda e qualquer atividade realizada no ambiente virtual pelo operador postal, que só tem acesso ao sistema mediante cartão (semelhante a um cartão bancário) e senha individual. Foram investidos no sistema em torno de R\$ 20 milhões, incluindo o software e equipamentos como balança, leitores e impressoras de códigos de barra, etc. (CONEXÃO..., 2004)

Esses elementos evidenciam que o governo Lula prosseguiu com a modernização iniciada no governo FHC, numa clara continuidade de projetos para esta área da estatal que buscava "maior controle, eficiência e qualidade". Tal continuidade pode ser observada ainda em programas voltados para o incremento da lucratividade por meio das vendas. Trata-se de direcionar as atividades da empresa aos clientes, como queriam os ideólogos da modernização que propuseram tal reorientação desde meados da década de 1990. 
Para a realização dessa empreitada, a ECT passou a incentivar programas de vendas e a estipular metas para seus funcionários. Nesse sentido, em 2004 a ECT promoveu a campanha denominada "Super Ação Vareja", com premiações para as Diretorias Regionais, regiões operacionais, agências e atendentes, ou seja, todos ficaram envolvidos com a meta estabelecida. Tratava-se de incentivar o desenvolvimento de uma "lógica comercial" por meio da concessão de casas, motos, carros, computadores etc. Quanto maior a venda, maior era a pontuação de um funcionário ou agência e a possibilidade de "ganhar" os prêmios. Buscava-se, com isso, aumentar não só as receitas, mas também estimular uma atitude permanente de comprometimento comercial.

Um exemplo do que a empresa buscava de seus funcionários foi assim apresentado:

O atendente comercial Lucas (DR-RS) é um caso de dedicação que rendeu bons frutos. Realizada em 2004, a campanha Conta Ponto serviu para que ele pudesse realizar o sonho de terminar a construção de sua casa. Apoiado pela família, especialmente pela mãe, Lucas dedicou-se ao máximo para alcançar suas metas. 'Não tinha sábado ou domingo. Todo dia era de Conta Ponto', lembra ele. Faltando só 15 dias para o fim da campanha, sua mãe faleceu. Mesmo abalado, Lucas não desistiu. Foi recompensado. Seu desempenho lhe garantiu prêmio de $\mathrm{R} \$ 1.413,00 \mathrm{e}$ uma moto. (CAMPANHA..., 2005)

A partir do exemplo apresentado pela própria empresa, fica evidente o tipo de funcionário que ela almejava: aquele capaz de se submeter às exigências de trabalho, até mesmo sem finais de semana - ou direito ao luto -, para manter o comprometimento com as metas da empresa.

Nesse sentido, é interessante observar os critérios para a eleição do atendente comercial padrão, a saber: "assiduidade, pontualidade, qualidade no atendimento, proatividade, comunicação e resultados em vendas", já que a ECT

'valoriza os campeões em vendas', como Denise (DR-RJ), que 'foi destaque nas campanhas 'Caça ao Tesouro' e 'Resgate suas Vendas', enquanto Ivete (DR-PR) e Raquel (DR-SPM) foram vitoriosas na campanha 'Sedex a 1.000 por Hora'. Silmara (DR-SPM), por sua vez, foi exemplar na cam- 
panha 'De Conta em Conta', ao abrir 1.045 contas-correntes do Banco Postal. Josenildo (DR-RN), Maria do Carmo (DR-BA) e Josefa (DR-RJ) brilharam nas campanhas 'De Conta em Conta', 'Caça ao Tesouro' e 'Resgate suas Vendas', respectivamente.' (VALORIZAÇÃO..., 2003)

Verifica-se, pelo "padrão" de trabalhador, que a estatal pressiona seus funcionários para alcançarem metas em vendas de produtos e serviços em seus guichês de atendimento, o que se associa à lógica mercadológica implantada nas lojas de atendimento da ECT. Deixa-se de ser apenas um ponto dos Correios para se tornar uma loja de serviços e, ao mesmo tempo, os atendentes comerciais são instados, em seu dia a dia de trabalho, a alcançarem metas de vendas, sendo todos os demais critérios colocados a serviço deste.

Diante disso, os trabalhadores informam que em sua rotina de trabalho a pressão para alcançar as metas se associa ao controle estabelecido pelos sistemas informatizados. Deve-se ressaltar que não são apenas críticas à tecnologia em si, mas aos problemas decorrentes, como se observa nos depoimentos a seguir:

Costumo dizer que teoricamente o sistema SARA é perfeito, mas na prática isso nunca aconteceu. Pra fazer um sistema como esse funcionar tem que ter investimento e isso é uma coisa que a ECT não faz.

(MARCOS, out. 2011, Atendente Comercial) ${ }^{23}$

Já aconteceu comigo de faltar dinheiro... Eu dou o troco direitinho... mas chegou o fim do dia faltando dinheiro. É desanimador ter dinheiro faltando... Você sabe que não deu troco errado, sabe que pagou certinho aos aposentados e no fim do dia a maldita [diferença de caixa] tá lá...

(ALBERTO, out. 2011, Atendente Comercial)

As reclamações dos atendentes se estendem para procedimentos que apontam erros pelo SARA, sobretudo com erros no sistema que geram filas ou comprometem o atendimento. Além disso, erros no sistema que provocam uma diferença de caixa são comuns, de acordo com os atendentes;

23 Depoimentos coletados pelo autor. 
inclusive, recebem uma diferença mensal denominada "quebra de caixa" para saldarem a diferença, o que gera transtornos e reclamações.

A implantação de uma infraestrutura tecnológica nos Correios foi importante para a modernização de processos de trabalho dos atendentes comerciais e mesmo para a melhoria de serviços prestados aos clientes. A inovação decorre do avanço das tecnologias informáticas, acompanhando os demais setores da economia.

A modernização das agências de atendimento foi acompanhada por mudanças no processo intermediário de tratamento e triagem postal, discutido a seguir.

\section{MODERNIZAÇÃO E REESTRUTURAÇÃO DE UNIDADES OPERACIONAIS DE TRATAMENTO: AUTOMAÇÃO DA TRIAGEM EM CENTROS OPERACIONAIS}

As transformações no sistema postal da Europa têm contemplado também os processos de triagem dos objetos postais. Naquele continente, entre 1995 e 2000, firmou-se como tendência a automação dos sistemas de triagem.

Os operadores postais na União Europeia têm buscado introduzir processos autômatos de triagem como meio de redução dos custos com mão de obra e como forma de incrementar a produtividade. A redução dos custos com a força de trabalho é tida, inclusive, como o principal motivo para investimentos na automação. Além disso, possíveis ganhos de qualidade e celeridade ao processo são citados como motivos para investimentos nessas tecnologias. (PLS RAMBOLL, 2002)

$\mathrm{Na}$ ECT, a triagem ocorre nas unidades intermediárias, como os Centros de Tratamento de Cartas e Encomendas (CTCEs) ou Centros de Tratamento de Encomendas (CTEs), unidades situadas entre a captação e a distribuição dos objetos postais; ou seja, são unidades de tratamento responsáveis por direcionar os objetos captados aos lugares de destino. Encontra-se na etapa intermediária da cadeia do processo operacional, como se visualiza na figura 4 na introdução deste capítulo.

Na ECT existem 57 Centros de Tratamento, 7 Terminais de Movimentação de Cargas e 2 Centros de Tratamento de Correio Internacional. Esses 
centros operacionais, que existem em todas as Diretorias Regionais, têm sido automatizados e mecanizados de maneira crescente, dentro de um processo que não é recente, embora tenha se intensificado nos últimos vinte anos.

\section{FIGURA 2 - CENTRO DE TRATAMENTO POSTAL AUTOMATIZADO}

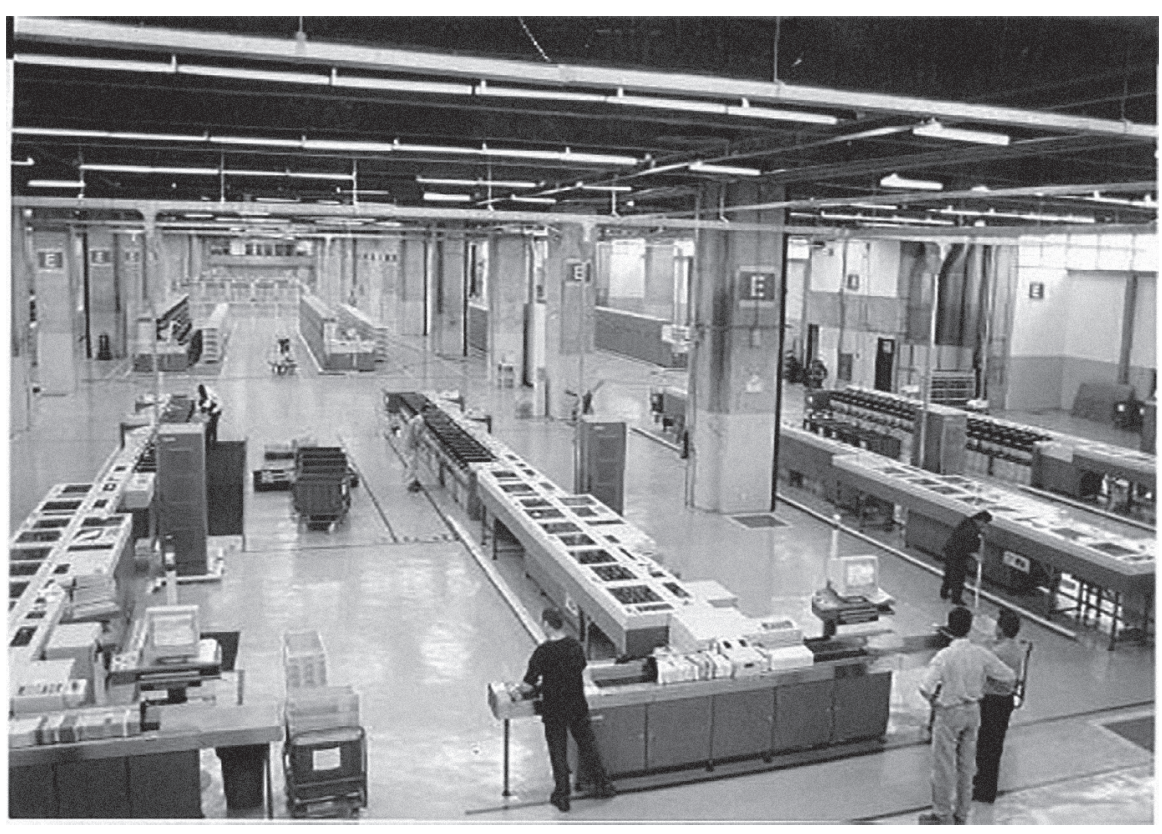

Fonte: BRASIL (2010) - Balanço de Governo.

Durante a década de 1970, o Projeto Eco reiterou as impossibilidades de substituição do carteiro na distribuição postal. No entanto, indicou a possibilidade de aprofundar a mecanização da triagem nos centros operacionais.

Os processos de separação e triagem, assim, poderiam valer-se da tecnologia e da mecanização, segundo os relatórios do projeto, como meio de implantar mudanças na estatal. Em razão disso, o diagnóstico deixado por eles acerca da mecanização pode auxiliar na compreensão do processo:

[...] o correio é, antes de tudo, uma empresa de mão-de-obra [sic] que, com exceção do setor de transportes, necessita muito mais de homens do que de máquinas; o funcionário do guichê será insubstituível ainda por muito tempo e no momento não vemos que substituto dar ao carteiro. Somente os grandes centros de triagem começam a ser dotados de poderosos meios mecânicos e automáticos, tais como transportadores aéreos ou esteiras, 
máquinas de triar cartas ou encomendas etc. E complementam: 'É importante assinalar que, apesar da utilização mais freqüente de máquinas de triar, no futuro a distribuição postal continuará dependendo do elemento humano'. E por fim concluem: 'Com efeito, para as tarefas de entrega a domicílio, o homem não pode ser substituído pela máquina.' (RELATÓRIOS DAS MISSÕES FRANCESAS apud BOVO, 1997, p. 39, grifo nosso)

O diagnóstico daquele momento continua valendo quarenta anos depois. No entanto, apesar de o trabalho do carteiro ainda ser insubstituível, pela natureza da tarefa, as atividades nos Centros Operacionais de Tratamento de objetos têm passado, sobretudo a partir da segunda metade da década de 1990, por um crescente processo de mecanização e automação. Mesmo período, portanto, em que se intensificou na Europa.

Em uma retrospectiva histórica, Barros Neto (2004) aponta que em 1971 iniciou-se a montagem do Centro de Triagem Mecanizado de São Paulo, sendo a inauguração realizada no ano seguinte. Já em 1976, as cidades do Rio de Janeiro e Brasília também contavam com um Centro de Triagem Mecanizado.

Segundo Bovo (1997), esses centros de triagem possuíam um sistema mecanizado e eletrônico de separação de malotes e encomendas. De acordo com este autor, havia uma máquina separadora de malotes e encomendas denominada Daifuku (adquirida da Toshiba Corporation), que ficava acoplada a um sistema de transporte aéreo e móvel, além de esteiras transportadoras. Tal sistema percorria vários andares e realizava a triagem de malotes e encomendas até o embarque dos objetos postais nos carros da empresa.

Os equipamentos e componentes do sistema presente no centro de triagem de São Paulo nessa época, de acordo com Bovo (1997), ligavam todos os pavimentos e dispunham

[...] de equipamentos mecânicos e eletrônicos tais como: transportador aéreo de pinças, transportador de correias geminadas, elevadores de carga, monta-carga, esteiras rolantes e shuts-rampas helicoidais e retas, instaladas no piso dos andares para descida das malas. (RELATÓRIO DAS MISSÕES FRANCESAS apud BOVO, 1997, p. 64-65)

Essas características dos sistemas mecanizados da década de 1970 indicam a inspiração fordista, situando os operadores de triagem e transbordo 
em posições fixas de trabalho e em um plano de tarefas estabelecido consoante às técnicas e ferramentas de racionalização do trabalho.

Na década de 1990, o governo de Fernando Henrique Cardoso destinou parte do orçamento de R $\$ 4$ bilhões do PASTE para a implantação de 86 sistemas de triagem automatizada de cartas e correspondências. Tais planos fizeram parte do Programa Corporativo de Automação Industrial (PCAUT), encerrado em 2006.

A partir de 1997, a empresa investiu com recursos próprios em torno de R\$ 194 milhões no programa, com os quais adquiriu 42 sistemas de triagem que tiveram sua instalação a partir de 1999. Para complementar os recursos necessários à compra dos 44 sistemas restantes, a empresa obteve o primeiro empréstimo externo de sua história no valor de $\mathrm{R} \$ 340$ milhões, de origem japonesa, francesa e dinamarquesa. Ao todo, a ECT investiu em torno de R 700 milhões para adquirir sistemas mecanizados e automatizados para tratamento e triagem de encomendas no formato normal, semiembaraçoso - envelopes - e encomendas. (DINHEIRO..., 2000)

Com o Programa de Automação Industrial a empresa objetivava diminuir os custos operacionais em pelo menos 30\%, além de aumentar a produtividade do processo de tratamento dos objetos postais. De acordo com o diretor de operações da empresa à época, "o nível de produtividade da área, de forma manual, já chegou ao limite.” (DE BRAÇOS..., 1999) Era a estratégia de aumentar o capital constante da empresa para atuação em um mercado postal em vias de se tornar liberalizado. Na Europa, os mesmos objetivos estavam sendo alcançados, com crescente correlação entre o aumento da produtividade e o investimento na automação.

Os prédios dos Correios que abrigam os sistemas de tratamento, de forma geral, possuem amplos espaços internos, cobertura metálica e revestimento acústico. De acordo com a empresa, foram adquiridos

85 sistemas de triagem automática de última geração para as cidades de São Paulo, Campinas, Ribeirão Preto, Bauru, Rio de Janeiro, Belo Horizonte, Curitiba, Florianópolis, Porto Alegre, Recife, Salvador, Fortaleza, Brasília e Goiânia. São sistemas que leem códigos de barras e endereços impressos ou manuscritos; e que separam objetos. (A IMPORTÂNCIA..., 2002) 
Desde 2003 o Programa Corporativo de Automação Industrial da ECT está implantado, cobrindo 80\% do tráfego postal brasileiro. Eram 56 sistemas de triagem para cartas e impressos sem volume, 15 para triagem de envelopes grandes (semiembaraçoso), jornais e revistas e 6 para encomendas, todos integrados ao banco de dados de endereços e informações da ECT.

Destes novos sistemas de triagem, o primeiro foi instalado e inaugurado em 1999 em Recife. Quando de sua implantação, possuía a capacidade de separar sete mil objetos postais por hora para até 75 destinos diferentes. (RECIFE..., 1999) Tal sistema era formado por duas máquinas capazes de realizar a triagem automatizada de cartas normais e outras duas destinadas às encomendas. Nesse equipamento, a triagem de encomendas e malotes era realizada por meio da leitura de códigos de barra presentes nas etiquetas ou pela digitação dos endereços.

No estado do Rio de Janeiro foi inaugurado em dezembro de 2001 o Centro Operacional de Benfica, com capacidade de triagem diária de 4 milhões de objetos postais, sendo o maior do estado fluminense e terceiro maior do Brasil e da América Latina. (CENTRO..., 2002)

Em São Paulo, o primeiro sistema de triagem automatizado foi inaugurado em 2000. Foram instalados neste estado quatro módulos de triagem: dois no Centro Operacional do Tietê e dois no Centro de Triagem Principal, no bairro de Jaguaré - onde o primeiro foi instalado.

O funcionamento do sistema automatizado ocorre a partir de um leitor de código de barras que identifica cada objeto postal. O equipamento possui cinco entradas. Inicialmente, o produto é erguido a partir do chão até o transportador. Este faz a pesagem automática, mede as dimensões dos objetos e, em seguida, distribui encomendas e correspondências em 156 bandejas que circulam sem parar por uma esteira a uma velocidade de 1,7 metros por segundo.

No Centro de Triagem Principal de Jaguaré havia, em 2010, três linhas de triagem com três equipamentos distintos: a máquina pré-separadora de objetos postais, a separadora final - que separa os objetos postais por itinerários de distribuição - e um módulo de supervisão.

A pré-separadora tem a função de ler o endereço e o CEP (impresso ou manuscrito) por meio de um sistema de videocodificação e consultar 
o banco de dados para a validação das informações para a impressão de códigos de barras fluorescentes nos objetos postais. Caso a pré-separadora não consiga reconhecer automaticamente nem o endereço e nem o CEP, uma imagem da carta é gerada e enviada aos postos de videocodificação para que um OTT tente identificar e complementar as informações do sistema a tempo de dar prosseguimento à triagem automática.

O sistema mecanizado e automatizado chamado de "separadora final" identifica as informações no código de barras e separa os objetos postais em até 216 faixas de CEP, pré-selecionadas a partir de um plano de triagem.

O módulo de supervisão faz o gerenciamento e coordenação de todas as atividades dos equipamentos, como a comunicação com a central em Brasília para envio e recebimento de informações estatísticas e também entre o banco de dados e os centros de triagem para envio e recebimento de dados acerca da triagem. Os sistemas implantados na ECT, de forma geral, utilizavam as mesmas tecnologias que os similares europeus à época. (PLS RAMBOLL, 2002)

FIGURA 3 - SEPARADORA FINAL DE CORRESPONDÊNCIAS NO CPT DE JAGUARÉ (2010)

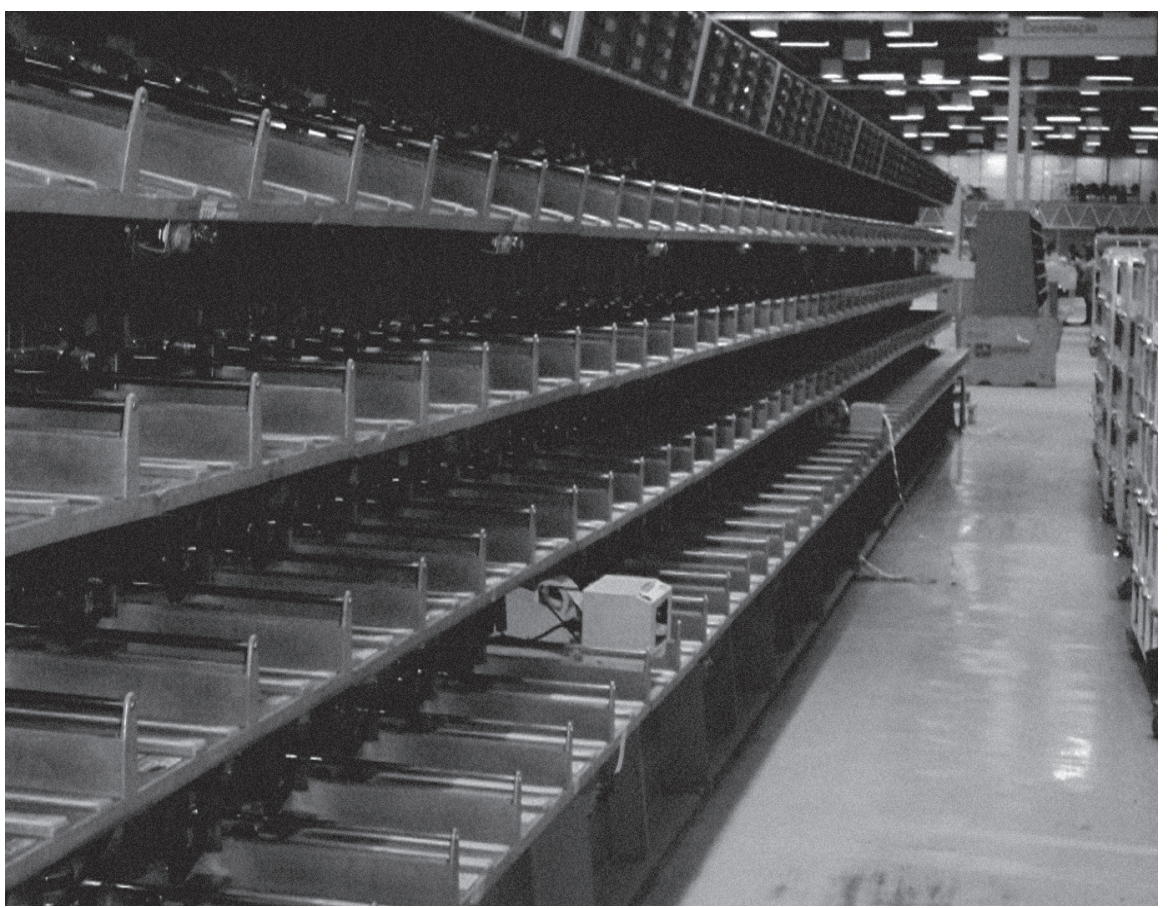

Fonte: Acervo do autor. 
No processo de triagem, as correspondências que por algum motivo não tiverem sido separadas pelos sistemas mecanizados são enviadas para a triagem manual. Aliás, o processo de triagem em Centros de Tratamento que não possuem os equipamentos necessários à separação mecanizada é realizado manualmente pelos operadores de triagem e transbordo em mesas de triagem com diferentes direções e escaninhos para separação dos diferentes destinos das correspondências. A mesa, que segue um padrão ergonômico definido para proporcionar tanto condições de trabalho adequadas quanto melhores condições para aumentar a produtividade do trabalho, pode ser visualizada na fotografia a seguir:

FIGURA 4 - MESA DE TRIAGEM MANUAL NO CPT DE JAQUARÉ (2010)

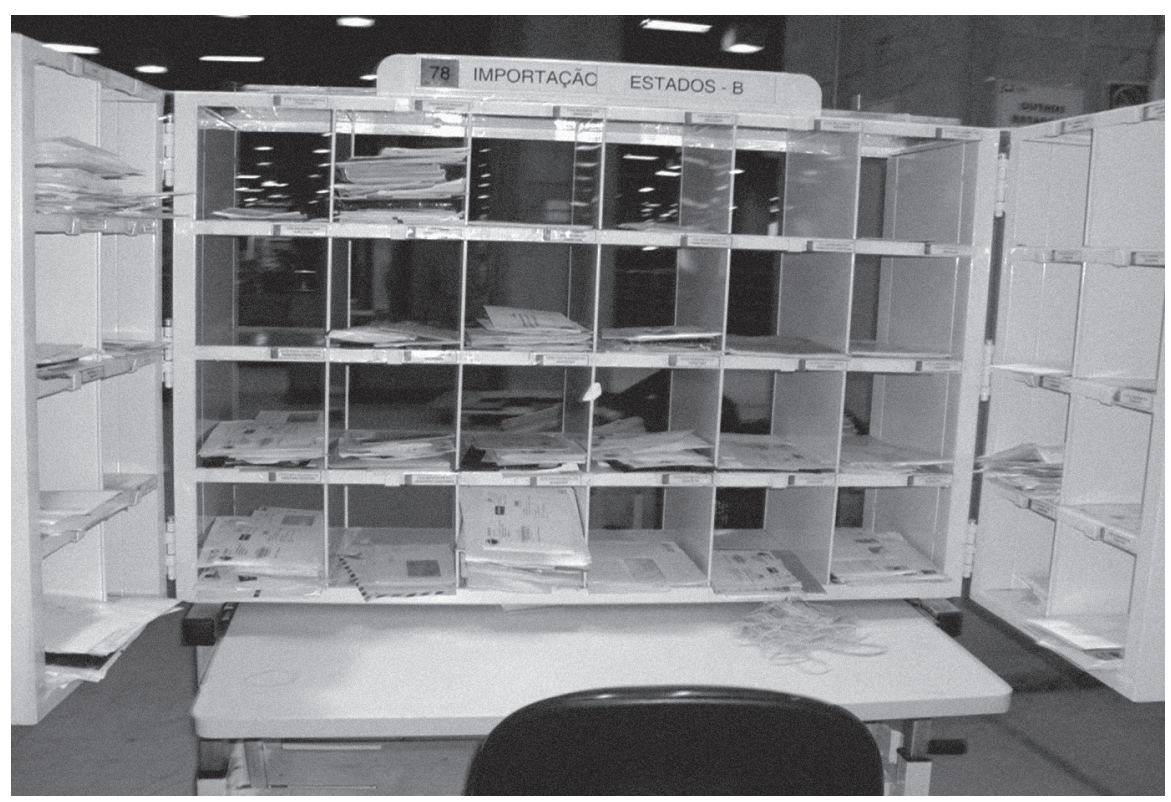

Fonte: Acervo do autor.

O processo de trabalho de triagem manual de objetos postais pelos OTTs se assemelha ao trabalho "interno" do carteiro, que será descrito e analisado mais adiante. ${ }^{24}$

24 Para uma descrição comparada entre a triagem automatizada e manual em Centros Operacionais de "Tratamento", ver a dissertação de Cruz (2007), desenvolvida a partir do enfoque analítico da administração da produção. 
O programa de automação industrial da ECT foi conduzido com bastante entusiasmo pelos dirigentes da estatal, que propalavam os benefícios trazidos pelas novas tecnologias, como se lê nos seguintes depoimentos:

[...] a incorporação dessas máquinas traz vantagens importantes aos empregados, pois reduzem o esforço físico e o tempo de processamento da triagem, ajudando a eliminar erros de encaminhamento e colaborando com o aumento da produtividade, fatores determinantes para a manutenção do sucesso empresarial.

[...] Há simplificação de operações e redução do esforço repetitivo e da movimentação de peso. Outra vantagem refere-se à melhoria da qualificação técnica dos trabalhadores. Empregados que nunca tinham utilizado computador, por exemplo, aprendem a operar equipamentos de alta tecnologia em ambientes modernos e de baixo nível de ruído. (A IMPORTÂNCIA..., 2002)

Além do aumento da produtividade - o objetivo primaz -, verifica-se que se acionava o discurso da qualificação dos funcionários como benefício indireto das mudanças. Para o coordenador do projeto de reformulação logística da ECT em 1999, "A automação tira as tarefas repetitivas do ser humano, mas não se automatiza a inteligência humana." (O IMPACTO..., 1999) Isto é, traria benefícios diretos aos empregados.

Dessa maneira, relacionava-se discursivamente a qualificação profissional com as tecnologias informacionais. É o que se verifica na entrevista do diretor de operações dos Correios em 1999, que ao ser questionado sobre as mudanças no dia a dia dos trabalhadores, respondeu:

Exige-se do empregado uma nova postura, que ele seja aberto a uma nova concepção de trabalho, num processo que vai lhe exigir novas habilidades no tocante ao manuseio e utilização desses novos recursos. Naturalmente, a empresa oferece e continuará oferecendo cursos de treinamento para que os empregados se adaptem à nova realidade. (DE BRAÇOS..., 1999)

No mesmo sentido, o diretor de recursos humanos afirmou que

Além dos cursos de rotina, há aqueles que adaptam o empregado às novas funções a serem desempenhadas. Novos negócios deverão demandar novos perfis profissionais, com migração parcial de funcionários 
para tarefas mais elaboradas. Ao se modernizar, a empresa automatiza várias funções para se adaptar à competição. Os empregados devem ter flexibilidade e abertura para encarar o processo. Graças a eles, os Correios são hoje uma empresa vencedora. Com a colaboração de todos, seremos ainda mais vitoriosos nos próximos anos. A manutenção do emprego traz segurança para que o processo siga adiante.

$\mathrm{Na}$ área de Recursos Humanos, todos os meios serão mobilizados para o treinamento adequado de cada empregado, de modo a melhorar suas próprias condições de empregabilidade. Cursos de atualização são sempre bem-vindos em momentos como o que vivemos. Os Correios incentivam a formação, a qualificação, o aperfeiçoamento e o autodesenvolvimento de todos os seus profissionais. Exemplos: em 1996, foram treinadas 12 mil pessoas em microinformática. Em 1997, foram 21 mil e, no ano passado, 23.500. Estamos implantando o sistema de educação à distância, facilitando o treinamento e a comunicação, além da Progressão de Incentivo Escolar, benefício ao empregado que completa grau escolar acima do exigido para a sua função. Isso é só o começo. (A HORA..., 1999)

O discurso da qualificação estava relacionado, neste contexto, à insegurança trazida pela introdução das novas tecnologias. Tal insegurança provinha do medo de demissões resultantes das novas tecnologias.

No continente europeu, a introdução de sistemas automatizados de triagem resultou no incremento da produtividade e no aumento das demissões no setor, em uma correlação direta entre os dois fatores, principalmente pela redução de centros de triagem e, consequentemente, de trabalhadores lotados nesses setores. (PLS RAMBOLL, 2002)

Assim, seria de se esperar que tal processo fosse desencadeado na ECT. Os trabalhadores, dessa maneira, sentiram o fantasma das demissões rondar muito próximo quando o programa de automação tornou-se efetivo.

No entanto, a ECT tratou de convencer os trabalhadores sobre a improcedência de tal medo. Em uma entrevista realizada em 1999 ao periódico corporativo, o diretor de tecnologia foi questionado se os investimentos em automação resultariam em desemprego, respondendo prontamente:

Não. Nos Correios, a ampliação da automação não significa desemprego. Temos a preocupação de requalificar e realocar o pessoal para outras áreas sempre que a introdução de tecnologia signifique mudar 
radicalmente a rotina de algumas funções. Com essa iniciativa, são criadas novas frentes de trabalho dentro da empresa. Aqui, a mão-de-obra [sic] é qualificada e preparada para integrar outros setores dos Correios. (AUTOMAÇÃO..., 1999)

Observa-se na fala do diretor de operações duas estratégias para afastar a insegurança das demissões: a qualificação para os OTTs operarem com as novas máquinas e a realocação dos funcionários considerados excedentes em outras áreas da empresa. No mesmo sentido, o presidente da empresa em 1999 afirmou que "Isso [a automação] não significa ameaça ao emprego. Ao contrário: essas pessoas terão oportunidades em outras áreas da empresa, pois o setor está em franca expansão." (AUTOMAÇÃO..., 1999)

Como informava o diretor de operações da ECT à época, "Os profissionais das unidades automatizadas foram avaliados de acordo com o perfil exigido para novas funções e receberam treinamento adequado. Os demais foram realocados, sobretudo em Centros de Distribuição Domiciliar." (O IMPACTO..., 1999) Ou seja, os operadores de triagem e transbordo que não continuaram a trabalhar em suas funções foram deslocados, principalmente, para os CDDs. Ao explicar essa opção em detrimento das demissões, o diretor de operações a justificou:

Os Correios sempre utilizaram intensivamente a mão-de-obra [sic] na área de distribuição. Hoje já prestamos atendimento domiciliar a 74\% da população e, como há o compromisso público de se melhorar esse índice, precisaremos de um maior número de carteiros, por exemplo. Assim, se por um lado há a automação, de outro surge a necessidade de mais gente nas ruas. A introdução do sistema automatizado de triagem não significa demissões e redução de pessoal, mas realocação de mão-de-obra [sic] em áreas carentes de pessoal, como o setor de distribuição. Há o compromisso de se conduzir esse processo de transformação da melhor maneira possível, mantendo os empregos ou contratando outros. (DE BRAÇOS..., 1999)

Nos Centros de Distribuição eles passaram a prestar atividades de suporte ao trabalho dos carteiros. Como pode ser verificado pelos números de empregos na função, todavia, realmente não houve um decréscimo de funcionários. Assim, por exemplo, se em 2002 os OTTs somavam 11.300 
profissionais, em 2005 eram cerca de 13 mil. Atualmente (2011), os OTTs continuam com cerca de 12.900 trabalhadores, algo em torno de $12 \%$ da força de trabalho total da ECT. Apesar de em termos absolutos não ter ocorrido uma diminuição dos postos de trabalho, houve uma redução relativa ao se comparar com o aumento do número de carteiros e atendentes comerciais. Em outros termos, verifica-se que a automação deixou de demandar novos trabalhadores na função de OTT além dos necessários à manutenção dos sistemas.

A estratégia de não demitir os OTTs "excedentes" foi possível pelo reaproveitamento dos profissionais em áreas da empresa onde havia necessidade de mão de obra. Ao mesmo tempo, o contexto em que os investimentos nos sistemas tecnológicos estavam ocorrendo era delicado politicamente para iniciar processos de demissão de trabalhadores ou colocá-los em disponibilidade, já que estavam em curso discussões para aprovação da nova Lei Postal. Além disso, processos de demissão de funcionários, que são empregados públicos, não é uma ação administrativa corriqueira como nas empresas privadas, já que a única maneira juridicamente aceitável é por meio de processos administrativos transitados e que comprovem a "justa causa" da demissão. Assim, é preciso levar em consideração esses aspectos para compreender a estratégia dos diretores da ECT em reaproveitar os operadores de triagem e transbordo em outros setores da estatal.

É também importante destacar como o processo de modernização da ECT encarnado na automação acionou discursos diferentes nos governos dos presidentes Fernando Henrique Cardoso e Lula. Para os representantes do presidente FHC, portanto, os investimentos em tecnologia deviam ser compreendidos dentro do contexto de transformações previstas para o setor, como contextualiza o diretor de recursos humanos à época:

Bem, o ponto principal já foi assegurado pelos Correios: as reformas não vieram para demitir. A modernização dos Correios está ligada à sua capacidade de competição. Em dez anos, no máximo, teremos o fim do monopólio. As mudanças visam tornar a empresa mais forte, num quadro aberto, de muitos concorrentes. Ao mesmo tempo, porém, não vamos esquecer o papel social da empresa. (A HORA..., 1999) 
Na inauguração de um centro de triagem e encomendas em Goiás, projeto iniciado durante o governo anterior, o recém-empossado presidente Lula e o novo presidente da estatal afirmaram:

Os Correios são uma demonstração de como o Brasil, à medida que se respeita e acredita em si, pode competir em qualquer área. (presidente Lula)

Para o Presidente dos Correios, João Henrique de Almeida Sousa, a nova unidade trará benefícios significativos aos colaboradores, aos clientes e aos Correios. 'Os empregados trabalharão com melhores condições, os clientes terão seus objetos postais entregues mais rápido e com maior segurança e a Empresa verá sua produtividade aumentar.' (TECNOLOGIA..., 2005)

Diante desses elementos, verifica-se que enquanto o governo FHC acionava o discurso da competitividade e relacionava claramente os projetos de modernização à liberalização postal, o governo Lula passou a explicar o investimento na modernização como parte de um processo de constituição de melhores condições de trabalho e parte de um projeto de constituição de uma "empresa cidadã a serviço do povo brasileiro".

Nesse contexto, as ações dos agentes governamentais evidenciam o predomínio de ações gerenciais vinculadas aos processos de reestruturação produtiva nas atividades operacionais da estatal.

\section{ORGANIZAÇÃO DO PROCESSO DE TRABALHO EM CENTROS DE DISTRIBUIÇÃO DOMICILIÁRIA}

As transformações nos sistemas postais têm abarcado também a reestruturação das atividades nos centros de distribuição domiciliária. A busca pela flexibilidade, redução dos custos nas operações e aumento da produtividade têm levado os operadores postais da União Europeia a reestruturações nas rotinas operacionais. (ANDERLONY; PILLEY, 2002)

Nesse sentido, o caso sueco é significativo dos rumos das transformações nos centros de distribuição. De acordo com Erlandsson (2002), a liberalização do mercado e a reestruturação do sistema postal na Suécia conduziram à reestruturação dos processos operacionais do operador público.

A reestruturação foi realizada por meio de um programa implantado em 2000 e denominado "Best Method". O objetivo central do programa foi 
otimizar o processo de trabalho por meio da introdução de métodos de trabalho calcados na flexibilidade organizacional e no tempo para execução das atividades.

O programa teve como principais resultados a padronização dos procedimentos e a formalização do tempo de entrega. Houve, segundo a autora, a racionalização dos procedimentos de trabalho, que resultou em uma intensificação do trabalho pelo maior volume de objetos postais direcionados às unidades operacionais.

Segundo Erlandsson (2002), muitos fatores contribuíram para o incremento do volume de objetos postais nas unidades e para a intensificação das atividades, como o aumento do ritmo de trabalho, o aumento da capacidade física das unidades, além da menor flexibilidade reservada aos trabalhadores e da redução da participação dos trabalhadores na concepção do programa.

A ECT também investiu na reformulação de suas unidades operacionais de distribuição. Na estatal brasileira, os Centros de Distribuição Domiciliária (CDDs) são os responsáveis pela atividade de distribuição. Em 2011, a média de objetos postais distribuídos diariamente foi de 35 milhões, atendendo em torno de 40 milhões de domicílios. Para a distribuição postal, além dos 114 Centros de Entrega de Encomendas - de onde partem entregas especiais como Sedex especiais, encomendas etc. -, a ECT possuía cerca de 900 CDDs. Nos CDDs trabalhavam quase 55 mil carteiros, isto é, $51 \%$ da força de trabalho da estatal.

A organização do processo de trabalho em CDDs passou a envolver a partir do projeto GPAC processos e procedimentos que seguem a lógica da produção industrial de serviço, com o processo de trabalho tendo que seguir um sequenciamento, sincronização e padronização das atividades para aumentar a produtividade, funcionar com base no cumprimento de metas e aumentar a velocidade das operações. Tudo isso sob o argumento da necessidade de incrementar a produtividade e as "melhorias contínuas" nas atividades operacionais.

A produção industrial de serviço aplicada aos CDDs foi implantada ao se propor a reorganização dos procedimentos de trabalho pelo planejamento e sistematização de cada operação como se integrasse um 
"processo produtivo", nos termos da ECT (2006, p. 03), que a despeito de ser "bem distinto de uma linha de montagem de automóveis ou de eletrodomésticos", possui princípios básicos que são semelhantes, o que poderia aumentar a produtividade e a melhoria da qualidade dos serviços prestados caso fossem efetivamente implantados. Para isso, a empresa passou a tratar o processo de trabalho de forma sistêmica, visando a "eliminação de pequenas perdas, através da racionalização de rotinas operacionais", o que resultou na "otimização de procedimentos [nos] CDDs".

Os argumentos da estatal são citados, com as próprias categorias utilizadas, para se evidenciar como esteve subjacente à reestruturação dos Centros de Distribuição a produção industrial de serviço.

A ECT organizou os processos de trabalho, durante a década de 1970, a partir de orientações tayloristas. Porém, os procedimentos de trabalho ainda continuavam "artesanais", como afirmou o governo de Fernando Henrique Cardoso. Isso significa que a empresa objetivava aumentar o controle sobre as atividades de trabalho, retirando dos carteiros o seu saber-fazer, isto é, a dependência das habilidades e experiências individuais de cada trabalhador. $\mathrm{O}$ ritmo e experiência de trabalho de cada carteiro era, naquele momento, determinante para as atividades de distribuição postal.

A produção industrial de serviços postais buscou, em sintonia com o projeto GPAC, alcançar a "otimização" nos procedimentos, superando os particularismos e adotando a uniformização nos procedimentos e processos para tornar a gestão operacional mais produtiva. Segundo os Correios, com "a padronização é possível a produção em massa", mesmo que seja de objetos postais, além de permitir que as tecnologias de gestão, procedimentos e regulamentos cheguem mais rapidamente ao nível operacional, onde "as atividades de supervisão e controle são facilitadas". (ECT, 2006, p. 03-04, grifo nosso)

A produção industrial de serviço aplicada aos CDDs resultou de um dos mais importantes projetos desenvolvidos no âmbito do GPAC, o Sistema de Melhorias em CDDs (SMEL) - recentemente batizado de Padronização do Processo Produtivo (PPP), o que demonstra como a lógica de gestão industrial foi incorporada. Implantado pela primeira vez em 1998 no Centro de Distribuição Domiciliária de Mogi das Cruzes, em São Paulo, 
possibilitou ao CDD obter a certificação ISO 9002 já no ano seguinte, o que impulsionou a disseminação nacional do programa. Para garantir a efetividade do projeto, cada CDD passou a ser certificado pela empresa. Antes disso, contudo, uma equipe formada por especialistas em gestão da distribuição da administração central e da respectiva diretoria regional avaliavam in loco se a gestão do CDD estava conforme os procedimentos do SMEL/PPP. (CDDs..., 2000)

A partir de 2003, a estatal instituiu o Prêmio CDD Nota 10 para escolher, anualmente, três CDDs "mais eficientes em suas práticas de gestão". O prêmio, de abrangência nacional, premia um CDD de cada uma das três regiões pré-definidas. ${ }^{25}$ Os critérios para escolha dos CDDs se baseiam em indicadores dos processos operacionais que medem o desempenho das unidades e também se baseiam em desempenhos não relacionados diretamente às operações, como temperatura, luminosidade, condições sonoras, treinamento dos trabalhadores e infraestrutura. Além dos dados operacionais, disponíveis quase em tempo real pelos sistemas informatizados, inspeções são realizadas nos Centros de Distribuição para averiguar as condições operacionais reais das unidades. Os CDDs contemplados são premiados e os gestores e carteiros são convidados para realizaram palestras em outros CDDs. (ECT..., 2004)

Além destes critérios, os CDDs são hierarquizados

[...] de acordo com a pontuação obtida nos seguintes indicadores: restos de objetos simples a distribuir, índice de desempenho do CDD, posições ativas de trabalho ocupadas, índice de lançamento e baixa do SRO. [...] só participaram da disputa os CDDs que atenderem, inicialmente, a cinco pré-requisitos: existência do Sistema de Melhorias (Smel) implantado, Sistema de Distritamento (SD) atualizado, índice de Resto de Objetos Simples inferior a 1,29\%, mínimo de 75 pontos na pesquisa de desempenho não-operacional realizada entre os colaborados da unidade e classificação no Relatório de Desempenho do CDD (RDC). (A VEZ..., 2004)

25 As regiões são formadas por diferentes Diretorias Regionais. A região I abrange as DRs SPM, SPI, RJ e MG; a região II envolve as DRs BsB, GT, PR, RS, PE e SC; enquanto a III engloba as DRs AL, AM, CE, ES, MA, MT, MS, NO, PA, PB, PI, RN e SE. 
A premiação visa, como se depreende, estimular a manutenção da padronização dos processos de trabalho, isto é, além do controle exercido sobre os gestores dos CDDs para que mantenham as prescrições nas atividades de trabalho, envolver os trabalhadores para que estes se comprometam com as estratégias de gestão do trabalho.

Com isso, verifica-se que na ECT a verticalização das decisões permanece. Na área operacional, cabe aos gestores de Centros de Distribuição apenas a aplicação das normas, procedimentos e padrões estabelecidos no Sistema de Melhorias de Centros de Distribuição/Padronização do Processo Produtivo. Em entrevista com um gestor de CDD, ele me disse que "tudo na empresa precisa seguir o manual", e por isso seria difícil alterar, como gestor local, mudanças nos métodos de gestão da empresa ${ }^{26}$.

De acordo com esse gestor, "há uma prescrição para todo o processo produtivo da empresa". "Não basta uma atividade ser realizada, ela tem de seguir a maneira correta de ser realizada". Nesse sentido, ele afirmou que a empresa busca, por meio de auditorias e de programas de certificação e concessão de "selos de qualidade", inspecionar se a padronização está sendo seguida. Um exemplo disso, segundo ele, ocorreu quando a carga da unidade que gerenciava estava muito acima dos índices estipulados para o CDD, o que estava impedindo o cumprimento de algumas normas na gestão do processo produtivo. Na ocasião, foi realizada uma visita surpresa de inspetores à unidade, que observaram que não havia carga acumulada. No entanto, verificaram que 53\% dos itens da padronização não estavam sendo seguidos, o que foi considerado um índice baixíssimo, mesmo sem carga a distribuir.

Ainda de acordo com o chefe da unidade, o manual padroniza tudo visando acabar com todo "obscurantismo, toda e qualquer dúvida sobre a forma correta de executar as atividades do processo de trabalho". Para ele, "não existe muita margem para os gestores das unidades realizarem suas atividades, porque tudo é normatizado, existindo uma hierarquia que deve ser seguida na instituição". Acerca disso, ele comentou sobre um CDD considerado exemplar, no qual "os carteiros são disciplinados ao extremo", pois

26 Depoimento prestado ao autor em trabalho de campo em janeiro de 2010. 
pela manhã, depois que todos os avisos foram dados e a carga do dia é informada, cada carteiro, cada qual em sua cadeira, levanta-se imediatamente e assim que o supervisor diz 'fim da reunião', começa imediatamente a TD, todos ao mesmo tempo.

É essa disciplina e controle "quase militar", como ele afirmou, que a empresa deseja.

A padronização nacional dos Centros de Distribuição é o objetivo, portanto, de programas como o "CDD Nota 10", que visa também à manutenção do consentimento dos trabalhadores na aplicação das estratégias de gestão. É o que fica claro na fala de um gerente de um "CDD Nota 10": "O que faz o empregado ser 10 é a sua motivação e o prêmio é um bom instrumento para manter as equipes engajadas no processo de melhoria contínua". (NA FESTA..., 2005)

Diante desses processos, duas perguntas estão em tela: 1) Como as estratégias de gestão do processo de trabalho foram organizadas a partir da lógica industrial em CDDs e quais as suas características? 2) Quais os impactos sobre as condições de trabalho e sobre as relações entre trabalhadores no local de trabalho?

\section{O layout dos Centros de Distribuição Domiciliária e a preparação das atividades de trabalho}

A organização do processo de trabalho em CDDs tem como ponto de partida a adequada disposição física dos equipamentos e postos de trabalho. O objetivo é "obter a mais eficiente e econômica inter-relação entre os homens, equipamentos e movimentação de materiais dentro de um espaço disponível." (ECT, 2006, p. 08)

O layout do CDD, segundo as prescrições, tem que propiciar a eficiência, minimizando a movimentação de materiais e pessoas e, para isso, deve aproximar equipamentos e carga postal dos trabalhadores. (ECT, 2006)

As prescrições da ECT são para que os CDDs se instalem em pisos térreos dos imóveis. Caso isto não seja possível, a unidade deve providenciar sistemas de movimentação vertical da carga para que os carteiros ou operadores de triagem não façam esforços que os desgastem fisicamente ao descarregarem os carros e caminhões e ao transportarem os objetos 
postais para o interior da unidade. (ECT, 2006) Seguindo essa norma, nos CDDs onde realizei observações só havia um andar, o que dispensava máquinas e sistemas elevatórios de caixas.

No CDD onde realizei uma imersão entre 2005 e 2008 - denominado aqui de "CDD X" - a entrada da carga postal na unidade ocorre através de uma porta de aço, típica de estabelecimentos comerciais, permitindo que veículos da empresa - normalmente Kombis ou furgões - entrem na unidade, o que facilita o transporte de caixas para o interior da unidade.

Em todos os CDDs pesquisados encontrou-se uma área para manipulação e triagem de objetos postais registrados - cartas registradas, Sedex e encomendas com valor declarado, como talão de cheques, etc. $\mathrm{O}$ acesso à área é restrito aos funcionários autorizados, normalmente operadores de triagem e transbordo. Eles triam os objetos por área de distribuição antes de entregá-los aos carteiros. O isolamento da área é feito com a utilização de balcões ou divisórias. Caso seja necessário aumentar o efetivo de funcionários desse setor em decorrência do aumento da carga, a empresa recomenda "empregados previamente escolhidos entre os de maior confiança da chefia." (ECT, 2006, p. 32)

A área de tratamento de objetos especiais deve estar próxima à entrada dos CDDs, já que são os funcionários do setor que fazem os atendimentos aos clientes que eventualmente retiram suas encomendas na unidade de distribuição. Para atender à norma, a área destinada ao tratamento de objetos especiais no "CDD X" está localizada na entrada do imóvel, separada dos funcionários e do público em geral por meio de balcões que, além de divisórias, também são utilizados pelos carteiros como mesa de apoio para colocar os objetos postais especiais em ordem de distribuição.

As mesas dos carteiros destinadas à triagem de objetos simples devem estar dispostas no formato de um "U" ou de um "W" (duplo U), "de modo que seja facilitada a movimentação de carga e a supervisão visual.” (ECT, 2006, p 08) Estabelece-se ainda que "as mesas dos supervisores devem estar localizadas de frente para o 'U' ou para cada parte do ' $W$ ', permitindo a visualização de todo o grupo de trabalho.” (ECT, 2006, p. 08)

No "CDD X", as mesas dos carteiros são dispostas em "U" e colocadas lado a lado, o que também foi observado nas demais unidades. O layout 
em "W" é utilizado, normalmente, em unidades onde há um número elevado de carteiros ou espaços pequenos. A mesa do supervisor de operações fica localizada de frente para a abertura do "U", o que lhe permite a supervisão visual de todo o processo de trabalho. Na Figura 5, observa-se a disposição em "U" das mesas de triagem e os balcões da área de tratamento de objetos especiais.

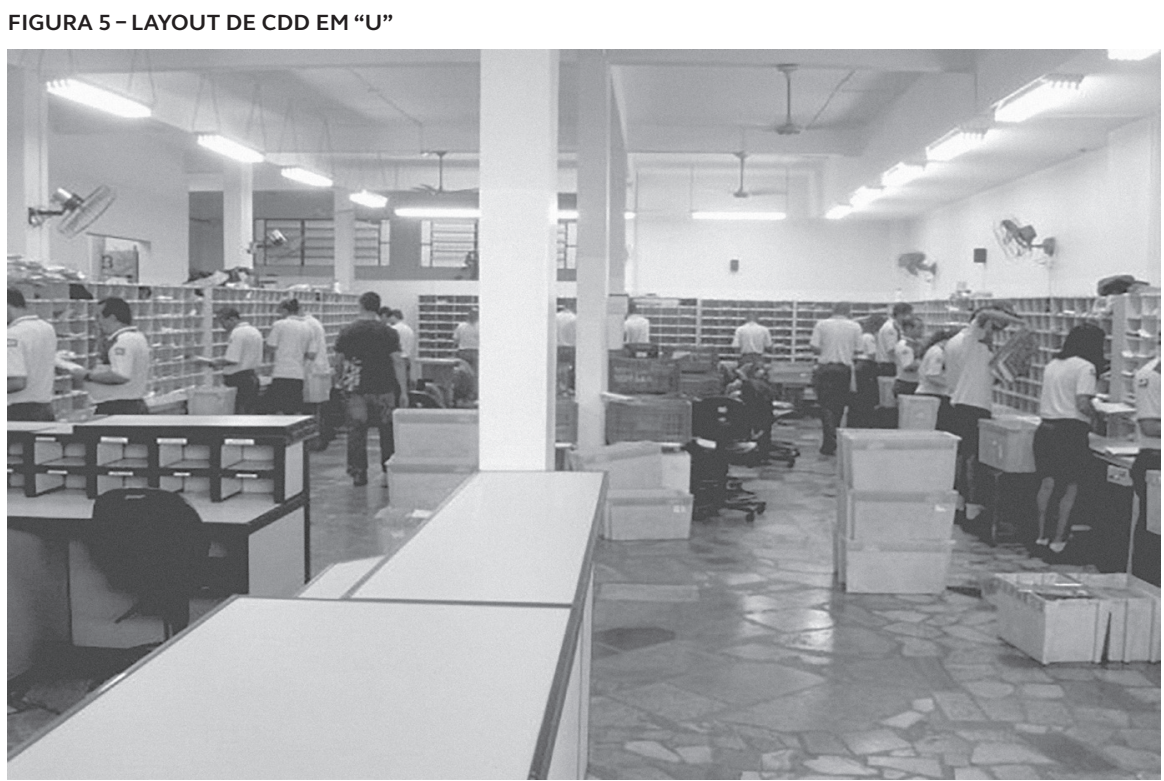

Fonte: Acervo do autor.

O layout escolhido para a organização do trabalho em CDDs atende aos critérios e diretrizes do toyotismo - pré-condição para que os demais princípios sejam alcançados. (CORIAT, 1994; CORRÊA, H. L.; CORRÊA, C. A., 2006) Prioriza-se o layout celular linear ao se trabalhar com uma gama limitada de produtos, porque seria aplicável a processos que se destinam à produção de quantidades maiores de produtos padronizados. Nesse tipo de layout, os postos de trabalho são colocados próximos para evitar supostas movimentações desnecessárias. Como a triagem de objetos postais simples não apresenta variações, o layout celular linear em forma de " $U$ " é empregado na maioria das unidades de distribuição. Ao abrir o "CDD X" para recepção da carga postal, a equipe encarregada deve observar 
aspectos como as condições dos objetos, a forma como estão acondicionados, se apresentam sinais de violação, além de averiguarem o franqueamento dos objetos, isto é, se não há uma evasão de receitas por falta de "selos" ou carimbo de franqueamento. (ECT, 2006) Caso haja alguma inconformidade ou irregularidade, a unidade expedidora do objeto postal é autuada para prestar explicações.

Dessa forma, o controle dos objetos postais é feito desde a recepção da carga e continua durante o processo de trabalho, incluindo o abastecimento das posições de trabalho e a triagem realizada pelos carteiros. Estes, inclusive, são orientados a separar as correspondências com irregularidades. Dessa maneira, os cuidados com a qualidade e as condições dos objetos se iniciam antes que haja a triagem e continua durante todo o processo operacional.

A verificação da qualidade dos objetos durante todo o processo de trabalho está associada aos princípios da Qualidade Total, que prescrevem a inspeção da qualidade nesses moldes. Associada ao modelo toyotista, a Qualidade Total pressupõe que eventuais não conformidades constatadas durante o processo de trabalho devam interromper a produção até a resolução. (CORIAT, 1994; CORRÊA, H. L.; CORRÊA, C. A., 2006)

Nos Correios, entretanto, caso alguma irregularidade seja constatada durante o processo de triagem, o carteiro não pode se ausentar da posição de trabalho: deve deixar o objeto irregular à parte até a triagem ser finalizada e, somente então, comunicar ao supervisor de operações o problema.

O tamanho e o formato dos objetos que chegam aos CDDs são observados no momento de preparação das atividades de trabalho porque "já no momento de recebimento da carga e formatação das tarefas, deve ser feita a contagem dos objetos simples recebidos." (ECT, 2006, p. 10) A contagem dos objetos é feita por meio do número de caixas que comportam certa quantidade previamente estabelecida de objetos postais de cada formato.

A mensuração é feita para que o supervisor de operações controle o dia de trabalho segundo os índices estipulados para a unidade. $O$ controle é realizado pela soma total dos objetos postais enviados aos CDDs. Como cada unidade tem um número fixo de carteiros, divide-se a carga da unidade pelo total de carteiros. O resultado indica a quantidade de objetos 
postais que cada carteiro deverá triar. Assim, pode-se ter uma previsão do término da triagem e um controle sobre o processo de trabalho.

Isso pode ser mais bem compreendido por meio de um exemplo baseado na rotina de trabalho do "CDD X": a média de objetos postais que chega à unidade por dia está em torno de 148 mil. Como são 25 carteiros que realizam a triagem, a média de objetos para cada um manipular é de 1920. O índice determinado para cada carteiro é de 1920 objetos por hora. Sendo assim, presume-se que a triagem terá uma hora de duração. No "CDD X", o quantitativo de objetos postais é afixado em um quadro de frente para o "U", de forma que todos os carteiros visualizem a carga do dia e o horário de início e a previsão de término da triagem. As atividades de trabalho em Centros de Distribuição são organizadas, assim, em índices e resultados.

A influência do toyotismo aparece ao se considerar que o aumento de produtividade e o controle do processo de trabalho reduzem os estoques e maximizam as operações. Tais orientações se manifestam na manutenção de índices de triagem que garantem a vazão das correspondências que chegam à unidade, de tal forma que ao final do expediente haja "resto zero" de correspondências, isto é, nenhum objeto postal a distribuir.

Antes do início da triagem, no entanto, e depois da mensuração da carga de objetos do CDD, há o abastecimento das posições de trabalho com as caixetas que contêm os objetos postais. Os formatos devem estar separados, isto é, primeiro são dispostas as caixetas com formatos maiores de objetos - "semiembaraçosos" e "embaraçosos" - e somente ao final da triagem que as caixas com "LC", objetos menores, como as cartas, são manipuladas. Apesar disso, o abastecimento ocorre uma única vez, com as caixetas dispostas entre as mesas dos carteiros e de forma perpendicular. (ECT, 2006)

Portanto, quando a carga de objetos postais está separada por formato, compactada e mensurada, é colocada em caixas que são posicionadas junto às mesas onde os carteiros as separam no processo de triagem. Os gestores recomendam que o setup seja realizado uma única vez, ou seja, que a preparação, abastecimento e desabastecimento das mesas dos carteiros para triagem das correspondências por distritos de distribuição e por logradouros sejam realizados em uma única etapa, evitando que ocorram deslocamentos das posições de trabalho. 
O abastecimento das mesas dos carteiros deve ser realizado sobrepondo-se as caixas, para que elas atinjam uma altura que possibilite ao carteiro pegar os objetos sem se abaixar. Além disso, as cadeiras dos carteiros devem estar separadas das mesas, permitindo a movimentação das caixas e dos carteiros sem que atrapalhem o processo de trabalho.

As atividades de preparação das tarefas do processo de trabalho finalizam quando todos os carteiros estão em seus postos no horário previamente determinado para o início da triagem de distribuição.

\section{Triagem por distritos de distribuição e desabastecimentos de mesas de triagem}

A triagem por distribuição (TD) consiste na separação de objetos postais pelos carteiros de acordo com os distritos do CDD. Distritos são áreas circunscritas de tamanhos variados - poucas ruas a bairros -, delimitados pela relação entre percurso do carteiro e quantidade de objetos a distribuir. Assim, cada CDD é responsável por uma área e deve criar ou reduzir distritos de distribuição conforme a carga de trabalho.

O processo de triagem por distribuição (TD) é a primeira etapa de trabalho dos carteiros no CDD. É o momento em que a carga compactada e disposta em cada mesa de triagem está preparada para ser "tratada" pelos carteiros, isto é, separada a partir da faixa de CEP ou pelos nomes das ruas de cada distrito. A TD deve iniciar-se no mesmo horário para todos os carteiros. Nesse momento, duplas de carteiros devem ser formadas, sendo que entre eles é deixada uma das caixas com os objetos postais a triar.

A triagem deve começar ao mesmo tempo para todos os carteiros. Se houver algum atraso, a triagem deve iniciar com os presentes - sempre em dupla. À medida que chegam, devem ocupar as posições disponíveis. Assim, nem sempre os carteiros ocupam durante a TD a sua mesa de triagem. Todo o processo deve ser realizado com os carteiros em pé para um melhor rendimento da triagem. (ECT, 2006)

As duplas de carteiros para a TD precisam ser formadas, segundo a ECT (2006), por carteiros com índices de produtividade diferenciados, de maneira que os mais produtivos estejam juntos com os menos produtivos, 
isto é, que os carteiros que conseguem atingir ou superar os índices de triagem estejam próximos, ou juntos, dos carteiros que não alcançam tal coeficiente. Esse padrão de triagem, que deve ser mantido pelos carteiros como um padrão "mínimo", precisa ser mantido por toda a TD.

Além disso, o carteiro precisa obedecer algumas prescrições para manter o ritmo e a disciplina ao manipular os objetos postais, como não pegar grandes quantidades de objetos, usar o polegar para a passagem das cartas e esclarecer dúvidas somente ao final da triagem. Para melhor rendimento da TD devem ainda ser tomadas atitudes que evitem a dispersão do carteiro, já que isso poderia acarretar uma diminuição no ritmo e na disciplina do trabalho. Essas atitudes seriam a circulação de carteiros dentro do CDD, conversas paralelas, uso de aparelhos sonoros individuais, o abandono das posições de trabalho etc. (ECT, 2006)

As normatizações comportamentais que os carteiros devem seguir integram as medidas adotadas pela empresa para aumentar a produtividade, o que evidencia como ela incorporou ao seu cotidiano gerencial recomendações acerca da racionalização, além de indicar como a disciplina corporal - marcada, inclusive, pela necessidade de ficar em pé durante a TD - é fundamental nesse contexto.

A separação da carga por formato e ordem de triagem - "semiembaraçosos", como envelopes devem ser triados antes de objetos em formato simples - auxilia o gestor a estabelecer a prioridade dos objetos que devem ser distribuídos em casos de contingência como greves.

A triagem deve ser realizada preferencialmente pelo CEP a fim de evitar a memorização de ruas e diminuir o coeficiente de dupla manipulação, ou seja, o encaminhamento de ruas para distritos de distribuição aos quais não pertencem. As direções de triagem nas mesas são indicadas por etiquetas amarelas com a faixa de CEP ou pela indicação do distrito (ao qual é atribuído um número). Outra etiqueta, de cor branca, é afixada nas divisórias das mesas (escaninhos) para orientar a separação das correspondências por logradouros.

Em alguns CDDs, como o "CDD X", há uma dupla triagem denominada, respectivamente, de Triagem por Distrito 1 e Triagem por Distrito 2. Consiste na divisão do CDD em duas regiões de distribuição. Se um município, 
por exemplo, possui dois polos regionais aos quais chegam muitas correspondências, podem ser criados dois setores de triagem: subsetores A e B. Sendo assim, quando a Triagem por Distrito termina em um subsetor, deve continuar com as correspondências repassadas de uma região para outra. Nesse processo, o layout em "U" facilita a divisão do CDD em setores de triagem - com cada lado do "U" separando objetos postais de uma região específica. Se a triagem não for concluída no mesmo instante nos dois setores do CDD, deve haver repasse de carga entre subsetores até o término da triagem.

Durante o processo de triagem, o supervisor de operações desempenha papel fundamental. A ele cabe a responsabilidade de observar e resolver problemas como "falta de abastecimento adequado; morosidade de algum carteiro; manutenção desnecessária de alguma dupla incompleta; excesso de mal encaminhados de um distrito para outro etc." (ECT, 2006, p. 17)

Nessa organização do processo de trabalho, verifica-se como o controle exercido pela empresa resgata a imagem, presente no taylorismo e fordismo, dos trabalhadores como partes de uma "máquina produtiva." (BRAVERMAN, 1987) Nesse sentido, o fato de os carteiros serem orientados a esperar em seus postos as caixas com objetos postais e a tentativa de controle comportamental alinham-se à concepção taylorista e fordista, que prescrevia a manutenção dos trabalhadores em seus postos de trabalho sendo abastecidos pela linha de montagem com materiais e matérias-primas necessários às atividades produtivas.

A fixação do trabalhador em seu posto de trabalho proporcionou enorme aumento de produtividade às indústrias fordistas, resultado que inspira os Correios na busca pela eficiência e produtividade. No entanto, é preciso destacar que o layout em "U" possibilita a constante realocação dos carteiros pelo supervisor de operações conforme a necessidade de aumentar a triagem em um dos subsetores.

O revezamento de carteiros entre distritos exige um conhecimento maior dos processos de triagem, apontando para uma necessária ampliação dos conhecimentos desses profissionais sobre as atividades de trabalho dentro do Centro de Distribuição. 
Além disso, observa-se que os estudos de tempos e movimentos influenciaram a condução do processo de trabalho nos CDDs, já que os índices de triagem e até mesmo os movimentos das mãos devem ser mantidos conforme o padrão de disciplina corporal exigido. Além disso, possibilita remanejar funcionários entre setores ou distritos conforme 0 volume e necessidade de trabalho, garantindo relativa flexibilidade às estratégias gerenciais.

No mesmo sentido, os índices são imprescindíveis ao planejamento operacional diário, sendo utilizados para calcular a quantidade de carga postal que cada trabalhador deve triar em certa quantidade de horas e com tempo suficiente para a distribuição. Sobre isso, Braverman (1987, p. 151) afirmou que o taylorismo buscou "tratar os próprios trabalhadores como máquinas", sendo que o estudo dos tempos faz parte do empenho em controlar o processo de trabalho. Esse é um elemento tão importante na rotina operacional dos Correios que um quadro com informações sobre o controle diário de trabalho é afixado em local visível a todos os funcionários.

Com o término da triagem por distritos, os carteiros iniciam, imediatamente, o desabastecimento das mesas de triagem. Para isso, cada carteiro deve utilizar a caixa destinada ao seu distrito - caixa "cativa" - para recolher de mesa em mesa, sempre no sentido horário e em sincronia, os objetos destinados aos logradouros do seu percurso.

Assim, o desabastecimento das mesas deve ser realizado no estilo "dominó" e em uma única etapa sequencial sincrônica, como visualizado na figura 15. Nessas ocasiões, o supervisor de operações orienta os carteiros para que evitem os "gargalos", isto é, o recolhimento das correspondências em uma única mesa de triagem ao mesmo tempo, devendo respeitar certa distância entre si. As cadeiras dos carteiros durante o desabastecimento devem permanecer longe das mesas para não atrapalhar o fluxo.

O "gargalo", nesse contexto, refere-se ao erro que pode comprometer a produção e a padronização, pois caso o desabastecimento seja realizado de forma equivocada, todo o processo de triagem terá de ser refeito, ocasionando um retrabalho. 


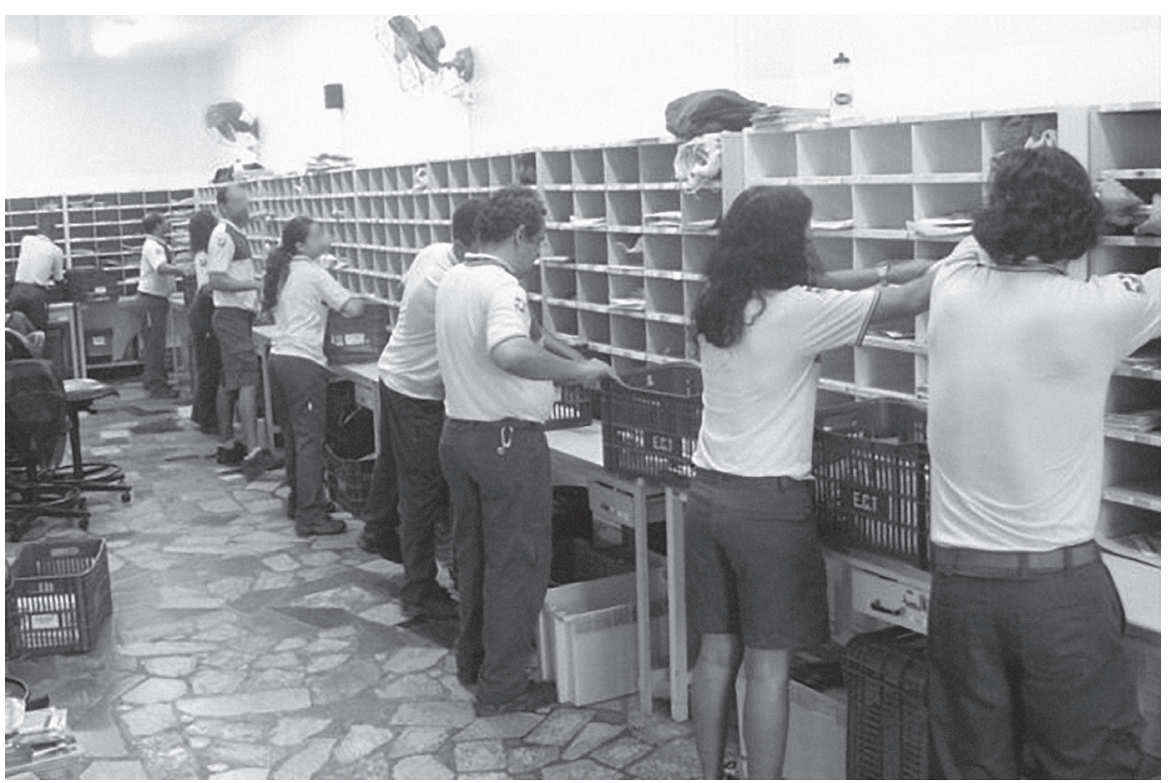

Fonte: Acervo do autor.

\section{Separação por logradouros e ordenamento dos objetos postais}

O processo de trabalho, depois do desabastecimento das mesas de triagem, continua por meio da separação das correspondências. Esse segundo processo de triagem consiste na separação dos objetos postais por rua a que se destinam dentro de cada distrito de distribuição postal. As mesmas direções das mesas de triagem utilizadas para separar as correspondências por distrito são agora utilizadas para separar os objetos postais por ruas e por trechos de ruas, observando-se, inclusive, a numeração dos endereços dos destinatários.

Esta etapa do trabalho do carteiro é realizada com base na seguinte diretriz:

A Separação por Logradouro (SL) representa uma das fases mais delicadas do processamento dos objetos simples, por ser feita individualmente, exigindo um acompanhamento constante por parte dos SOs (supervisores operacionais). Tal preocupação se prende à necessidade de se evitar que todo o ganho de tempo, obtido até então com a obtenção de tarefas e o trabalho em equipe, seja desperdiçado em face das limitações de rendimento individuais. (ECT, 2006, p. 20) 
Verifica-se no excerto a orientação taylorista que preconiza a necessidade dos trabalhadores executarem suas atividades de acordo com padrões universais que lhes são impostos, excluindo qualquer individualidade que por acaso possa existir nas atividades que desenvolvem. Como parte desse processo, o supervisor de operações é orientado a estar presente para verificar se o trabalho executado está ou não de acordo com as metas e padrões estabelecidos.

Com isso, o princípio taylorista que preconiza a separação entre as atividades de execução e as atividades de concepção apresenta-se novamente, já que a única responsabilidade do carteiro é a execução das atividades. Além disso, a própria figura do "capataz" que o taylorismo preconiza como necessária ao controle do trabalho é incorporada no processo na figura do supervisor de operações.

Apesar do controle e das normas, o trabalho de separação das correspondências por logradouros é executado no "CDD 1" de acordo com as peculiaridades de cada carteiro. Uns são mais ágeis e mantêm os índices de triagem e mesmo os superam, terminando, assim, a atividade antes dos demais.

Além disso, as características de cada distrito também influenciam o desempenho de cada carteiro, já que a quantidade e os tipos de pontos de entrega influenciam a separação das correspondências. Em muitos casos, os carteiros utilizam inclusive a mesa de triagem como espaço para separar trechos de logradouros, embora isso esteja fora das prescrições. Nesses casos, o supervisor de operações não intervém para impor a forma "correta" de separar as correspondências em razão das características de cada distrito, que podem ter muitas ruas ou mesmo uma quantidade de grandes usuários, aumentando o volume de correspondências de uma determinada área.

Compreende-se, assim, que a prescrição do trabalho, indicando não só como realizá-lo, mas também os meios para a sua execução, nem sempre é seguida. Pelo contrário, o trabalho real contempla renormatizações quando efetivado por cada carteiro. Dessa maneira, há sempre um distanciamento entre a prescrição e a ação efetiva de cada trabalhador, o que impossibilita o controle absoluto das atividades - objetivo dos departamentos responsáveis pela concepção e planejamento do trabalho, sobretudo quando orientados pelo taylorismo. (TELLES; ALVAREZ, 2004) 
Segundo os trabalhadores que entrevistei, há menos controle na triagem por logradouro por ela ser uma atividade individual do carteiro, relacionada ao seu próprio distrito. Além disso, muitos trabalhadores alegam ficar mais de quatro horas em processo de triagem, o que torna a permanência em pé bastante extenuante.

Isso mostra, como afirmou Estanque (2005), como o taylorismo nunca conseguiu, efetivamente, separar execução e gestão, por mais que os gestores tenham tentado monopolizar o controle técnico do trabalho. Segundo o autor, é o saber-fazer operário que lhes permite, sutilmente, contrapor-se às regras hierárquicas.

No CDD analisado, observaram-se objetos postais sobre a mesa de triagem, procedimento que é proibido. Os trabalhadores devem triar as correspondências unicamente nos escaninhos. No entanto, os entrevistados alegaram que em algumas ruas há pontos que recebem muitas correspondências e, nesses casos, separá-las facilita os procedimentos posteriores.

No mesmo sentido, a empresa envida esforços para manter a disciplina e a ordem, como exemplificam as tentativas de impor o silêncio no ambiente de trabalho e o controle sobre a maneira como a triagem é realizada. Ao ser questionado sobre os procedimentos durante as duas etapas da triagem, um funcionário destacou:

\begin{abstract}
Aqui ambas são realizadas em pé. Acho que, ergonomicamente, efetuar a separação sentado seria prejudicial à saúde, pois teríamos que forçar mais o braço para alcançar os pontos mais altos. Mas como dizem por aqui: 'Se o seu distrito for zerado [não tiver nenhuma carta para distribuir ao final do dia] à tarde, você pode triar de costas, de cabeça para baixo.' [...] (ROBERTO, out. 2009, carteiro) (TEIXEIRA, 2010, p. 142)
\end{abstract}

Isso aponta, portanto, para a realização da triagem a partir de características de cada carteiro, o que resulta em atitudes que desafiam as tentativas de racionalização comportamental:

$\mathrm{Na} T \mathrm{D}$ realmente tem que ser em pé e em silêncio. Eu não fico calado um instante o dia todo. Mas depois [Na SL] é tarefa individual e a pessoa é livre pra executar dentro dos tempos [de triagem]. (MARCOS, ago. 2009, carteiro) 
Eu sou quase sempre o primeiro a acabar de triar e ordenar, então tá provado que isso não atrapalha [conversar durante a triagem], a empresa deve parar de ficar inventando regras e metas absurdas e dar melhores condições de serviço. (JOÃO, out. 2009, carteiro) (TEIXEIRA, 2010, p. 142-143)

Eu também sou um cara que fala muito, tanto na TD quanto na SL, e não atrapalha em nada o andamento do serviço, afinal de contas, jogo carta com a mão e não com a boca. (RODRIGO, out. 2009, carteiro) (TEIXEIRA, 2010, p. 143)

Depreende-se, portanto, que os métodos de gestão empregados objetivam também impor a disciplina e a racionalização comportamental, principalmente em relação às conversas e brincadeiras entre os carteiros, que resistem ao "silêncio".

Só que tem supervisor que lê a porcaria do manual e lá tá escrito: 'SL tem que ser feita na velocidade de tantos objetos por hora e com concentração'. Daí o infeliz do chefete entende que a pessoa tem que ficar calada durante a TD, a SL, o ordenamento e se possível só dizer a ele que tá saindo [para a distribuição]. (MANOEL, 2009, carteiro) (TEIXEIRA, 2010, p. 143)

Esses conflitos ocorrem, principalmente, quando inspeções de instâncias superiores da área operacional estão programadas. Nessas ocasiões, os carteiros são efetivamente acompanhados pelos supervisores de operação e obrigados a seguir o procedimento prescrito. Fica, então, subentendido que no dia a dia há um acordo tácito entre supervisores e carteiros sobre a burla às normas prescritas, desde que estes cumpram a tarefa.

Mas os conflitos não deixam de estar presentes no dia a dia de trabalho. As tentativas de impor o silêncio entre carteiros, inclusive, ocorre em ocasiões em que "conversas" e, principalmente, brincadeiras tratam das relações de trabalho. No "CDD X", por exemplo, na parte da manhã, período em que os carteiros estão envolvidos nas atividades de triagem e preparação para a distribuição, constantemente os carteiros brincam entre si, seja caçoando dos trejeitos do colega, seja contando anedotas vivenciadas "na rua". Um dos casos observados relaciona-se à quantidade de trabalho. Quando a carga postal a distribuir em um dia era considerada grande, a reclamação aumentava e alguns carteiros começavam a cantar e a brincar sobre a situação. 
Parodiando a música Vida de Negro, de Dorival Caymmi - que tem a vida de um escravo como tema -, alguns cantavam: “Lerê, lerê, lerê". Nesse momento, outro carteiro realizava com a boca um som imitando algum tipo de chicote: "Xilepiti! Xilepiti?". Com a possível intervenção do supervisor para mandá-los cessar a brincadeira, outro gritava: "Cuidado, Joaquim [carteiro]! Carneirinho [apelido dado ao supervisor pelos carteiros] vai te colocar no tronco?". Em uma explícita alusão aos castigos sofridos pelos escravos, o "tronco", no contexto, significava possíveis intervenções do supervisor ou do chefe do CDD para silenciar as brincadeiras, com ameaças de sanções quando necessário. Quando "não estava demais", os chefes riam, juntamente com os carteiros, da troça. Nesse contexto, as brincadeiras expressam o descontentamento com o excesso de trabalho e possíveis punições pelos gestores.

Essas manifestações podem ser entendidas como "rituais de descompressão", como denomina Estanque (2000) ao analisar o papel do humor e das brincadeiras entre trabalhadores. São situações que podem transitar no contexto organizacional, segundo o autor, entre o controle institucional e a desmistificação do poder. Podem ajudar os trabalhadores a lidar com as adversidades do trabalho por meio da acomodação e aceitação ou, alternativamente, como um ataque e forma de resistência ao poder estabelecido. (ESTANQUE, 2000, p. 352-353)

Ao término da separação por logradouros, os carteiros iniciam o processo de ordenamento dos objetos postais, isto é, organizam os objetos postais a serem distribuídos na sequência de entrega aos destinatários. $\mathrm{O}$ ordenamento pode ser feito com os carteiros sentados em suas posições de trabalho junto às mesas de triagem. Para a realização dessa etapa de trabalho, os carteiros fazem uso do Boletim de Itinerário - documento que indica todos os procedimentos para a distribuição domiciliar, o que inclui referência de ônibus que passam no distrito, a ordem de distribuição nos logradouros e a respectiva numeração dos domicílios. (ECT, 2006)

O Boletim de Itinerário é a sistematização e normalização do conhecimento que o carteiro possui sobre o distrito. Sendo assim, os carteiros, quase sempre, memorizam toda a sequência numérica das ruas, os pontos de distribuição, a forma como a percorrida é realizada nos logradouros, 
etc. Dessa maneira, raramente o documento é consultado por algum carteiro que conhece e realiza a distribuição regularmente. No entanto, em situações em que há a ausência do carteiro titular, o Boletim de Itinerário é consultado pelo substituto para o ordenamento dos objetos postais. Por isso mesmo a empresa determina que "os titulares desses distritos são responsáveis pela atualização constante das informações contidas no Boletim." (ECT, 2006, p. 22)

Diante disso, fica evidente o intuito de extrair de cada carteiro o conhecimento que ele detém sobre o distrito. A atualização do Boletim de Itinerário é realizada pelo carteiro titular do distrito - o que mais conhece as peculiaridades, portanto, da distribuição postal em determinada localidade - quando ocorre a contagem anual das correspondências de um determinado $\mathrm{CDD},{ }^{27}$ devendo indicar as alterações nos percursos de distribuição.

\section{Atividades precedentes à distribuição postal}

Ao término do ordenamento das correspondências para distribuição, iniciam-se as atividades que antecedem a distribuição domiciliar. Dentre essas atividades, há a preparação de Depósitos Auxiliares - pontos "estratégicos" (estabelecimentos comerciais, edifícios, lojas etc.) localizados nos distritos para a guarda provisória de objetos postais que não podem ser transportados pelos carteiros por excederem o volume e peso permitido para transporte na bolsa do carteiro (máximo de $10 \mathrm{~kg}$ para homens e 8 kg para mulheres). Os depósitos são criados por iniciativa dos carteiros quando há uma sobrecarga de peso para transporte durante a distribuição. (ECT, 2006)

Os depósitos auxiliares são preparados e acondicionados em sacos para transporte pelos veículos dos Correios. A preparação inicia-se ainda durante a separação das correspondências por logradouros. As ruas onde há um maior volume de correspondência são triadas primeiro para serem enviadas aos depósitos auxiliares. Pude observar nos CDDs que

27 Trata-se de uma contagem de objetos postais de um CDD para verificação do fluxo postal de determinada região, o que pode resultar na criação de novas áreas de distribuição ou alteração dos distritos existentes. Esse processo é denominado "Redistritamento". 
quando há sobrecarga de trabalho ocorrem atrasos na preparação e entrega dos depósitos auxiliares, o que atrasa, consequentemente, a distribuição domiciliária.

Quando terminam de preparar os depósitos, os carteiros dirigem-se para o setor de objetos especiais do CDD, onde ficam os objetos registrados e Sedex. Para receber esses objetos dos operadores de triagem, os carteiros precisam assinar uma Lista de Objetos Especiais Entregues ao Carteiro (LOEC), atestando que todos constantes na lista foram recebidos. Para a entrega dessas correspondências especiais, o carteiro solicita assinatura do destinatário no momento da entrega.

Quando o carteiro volta da distribuição, a mesma lista é conferida. Caso haja a assinatura do destinatário no local correspondente ao objeto, significa que foi entregue. Caso não tenha sido, o carteiro precisa devolvê-lo ao responsável pelo setor de objetos especiais para que haja uma nova tentativa de entrega no dia seguinte. ${ }^{28}$ Caso o carteiro não tenha entregado a correspondência e nem retornado ao CDD com ela, responderá a um processo administrativo para explicar a falta da correspondência sob sua responsabilidade, podendo ser responsabilizado administrativa e criminalmente, caso haja algum extravio de valor e seja comprovado o dolo.

Quando a bolsa está com as correspondências, os objetos especiais conferidos e sob sua responsabilidade e os depósitos auxiliares preparados, os carteiros param para o almoço e, no retorno, preenchem o Sistema de Gerenciamento de Desempenho Operacional (SGDO) antes de sair para a distribuição. Ao preencher o SGDO eletrônico, o carteiro possibilita o controle diário das atividades de trabalho por meio das informações disponibilizadas no sistema, como o distrito em que está, o horário em que sai para a distribuição e retorna ao CDD, o peso da bolsa, dos depósitos auxiliares e das correspondências dos grandes usuários, e também se não foi possível distribuir todas as correspondências do dia (caso não haja "resto zero").

28 Os objetos especiais, como Sedex e registrados de uma forma geral, passam por três tentativas de entrega nos endereços dos destinatários. 
O Sistema de Gerenciamento de Desempenho Operacional é a versão eletrônica da planilha de Controle Diário de Depósitos Auxiliares e Grandes Usuários. São as mesmas informações que antes eram preenchidas manualmente que foram informatizadas a partir de 2008. Com o SGDO, torna-se possível acompanhar em tempo real todos os distritos do país e, consequentemente, controlar as atividades de trabalho de todos os carteiros. Para isso, foi disponibilizado um computador exclusivo para esta tarefa em cada CDD. Cada carteiro possui senha para entrar no sistema, que deve ser informada juntamente com a matrícula funcional. O que mudou, portanto, foi o aumento do controle sobre as atividades do carteiro com o emprego das tecnologias informacionais.

De acordo com supervisores de operações, há dados que não estão disponíveis aos carteiros, como as informações relativas e comparativas entre os distritos. Ao acessar o sistema, segundo os supervisores, é possível saber imediatamente de todas as informações relacionadas aos distritos. Caso o carteiro saia para a distribuição sem lançar as informações no sistema, por exemplo, uma luz de cor vermelha fica acesa - o mesmo ocorrendo durante o processo de triagem no início da jornada de trabalho.

Em um dos CDDs observados, quando o supervisor de operações me explicava o funcionamento do SGDO, o programa mostrou que um carteiro não havia preenchido o sistema antes de sair para a distribuição. Depois de um expressivo xingamento, disse que o carteiro teria que lançar os dados quando retornasse. Indaguei: "E nesse caso, o que acontece, não tem problema?". Ao que ele respondeu: "O problema é que as informações passam a contar no horário real [o time do sistema], ele não pode sair e chegar ao mesmo tempo, em dois minutos. Então a informação não é real, e eles sabem disso." "Eles", no caso, são os gestores regionais e hierarquicamente superiores, que têm acesso ao sistema de cada unidade e podem acompanhar todo o processo de trabalho e de distribuição da unidade e de cada funcionário. O gestor da unidade em que se passou tal fato, ao comentar sobre o sistema informatizado, fez a seguinte consideração:

Nesse sistema, os carteiros lançam os dados referentes ao seu distrito como faziam anteriormente, só que com a diferença que agora os chefes acompa- 
nham com mais controle, pois é possível emitir relatórios os mais diversos, tanto sobre o distrito como sobre o funcionário.

No Sistema de Gerenciamento informatizado, também é possível visualizar quando o carteiro está na distribuição, pois o sinal luminoso aceso no sistema é de cor laranja, o que indica que o carteiro ainda não retornou. No momento em que o supervisor me apresentava o SGDO, apenas um carteiro havia voltado da distribuição e, nesse caso, ao acessar o sistema, o sinal luminoso estava verde, indicando que o funcionário havia retornado e também o tempo em que esteve na atividade externa.

Cabe ressaltar que o carteiro tem acesso às informações pontuais sobre o distrito em que executa suas atividades, enquanto a planilha completa fica à disposição dos supervisores que possuem acesso pleno aos dados. No lançamento das informações, os carteiros preenchem os dados solicitados de seu distrito sem demonstrar preocupações com as demais informações, como a carga do dia, o efetivo na triagem e distribuição etc.

\section{Distribuição postal e a lógica do trabalho por tarefa}

A distribuição postal é a atividade final do processo de trabalho na ECT. Constitui-se em uma tarefa realizada por cada carteiro em seu distrito. Os distritos são concebidos a partir da relação entre quantidade de objetos a distribuir em certo percurso. Trata-se da "segunda etapa" das atividades de trabalho de um carteiro, quando ele deixa os centros de distribuição para o trabalho externo à organização.

A dimensão de cada distrito é feita por meio do Sistema de Distritamento, ocasião em que são contadas as correspondências de cada distrito para mensurar a área e verificar a necessidade de expandir o número de novas rotas. Isso ajuda a explicar por que os distritos são heterogêneos e comportam muitas diferenças entre si. Dentre os elementos que influenciam na definição de um distrito há a topografia, demografia, urbanização, arquitetura etc. Assim, alguns distritos são formados por poucas ruas e outros por áreas tão abrangentes como bairros. No primeiro caso, típico de bairros ou regiões verticalizadas, a quantidade de objetos a distribuir em cada ponto de entrega é maior, o que aumenta o volume de 
correspondências transportado por cada carteiro. Alguns carteiros com quem conversei, por exemplo, faziam a distribuição postal em duas, três ou quatro ruas, mas distribuíam cerca de $60 \mathrm{~kg}$ de objetos postais por dia. No segundo caso encontram-se os distritos que contemplam bairros, mas que normalmente apresentam baixo volume de correspondências.

As características dos distritos, portanto, estão condicionadas às características da divisão do território. Nesse sentido, há várias estratégias usadas pela ECT para a distribuição postal: uso de bicicletas, motocicletas ou a pé.

Os distritos têm, normalmente, um carteiro titular. $\mathrm{O}$ aprendizado de um novo distrito é feito pela transmissão do saber-fazer de um carteiro mais velho para o novato. Este irá decorar as ruas do distrito, a numeração e os pontos de entrega, além dos "macetes" - habilidades no trabalho externo que só a prática pode ensinar. Apesar dos gestores buscarem expropriar o conhecimento do carteiro sobre o distrito para que outro trabalhador possa fazer as atividades, a aprendizagem de um distrito é sempre mediada pelo carteiro mais experiente. Isso ocorre tanto no processo de socialização de um carteiro novato quanto no aprendizado de um novo distrito por um carteiro com mais tempo de trabalho.

O roteiro de distribuição segue o Boletim de Itinerário, atualizado pelo carteiro que mais conhece o distrito. Em outras palavras: apesar dos carteiros conhecerem mais de um distrito de distribuição - normalmente são treinados em três -, há um em que ele é "titular", conhecendo-o mais e, por isso, é o responsável por atualizar os pontos de entrega nos momentos em que há a contagem dos objetos postais no Sistema de Distritamento.

Há a tentativa organizacional de controlar o trabalho de distribuição dos carteiros. Nesse sentido, a presença de caixas de coleta nas ruas, por exemplo, torna-se, além de um ponto de recolhimento de objetos, uma maneira de verificar se o carteiro cumpriu o seu itinerário, já que precisa comprovar - por meio de giz de cera sobre a numeração da caixa de coleta - que esteve naquele ponto. Além disso, distribuir os depósitos auxiliares pelo distrito é outra maneira de fazer o carteiro percorrer o distrito, além de conferir, eventualmente, a bolsa dos carteiros ou os depósitos auxiliares enviados para o distrito quando regressam do trabalho externo. 
Apesar disso, o trabalho externo é tido pelos carteiros como o momento em que há mais liberdade na execução das tarefas, porque é realizado sem a presença de um gestor e por permitir que o ritmo de trabalho individual seja seguido.

Cada distrito tem um tempo médio para realização do trabalho de distribuição, sendo possível acompanhar o cumprimento e desempenho de cada funcionário pelo sistema informatizado (SGDO). Apesar disso, os carteiros entrevistados informaram algumas de suas táticas para evitar pontos de entrega em dias em que há uma sobrecarga de trabalho: burlar normas de entrega, como não chamar o destinatário da correspondência em edifícios nos quais a entrega é mais demorada, deixar de passar em algum ponto onde haja só propagandas para entregar etc. Trata-se, portanto, de desobediências às normas da empresa e são arriscadas para o trabalhador, porque podem lhe custar processos administrativos e, em último caso, até a demissão justificada.

Apesar disso, é possível verificar uma noção de "serviço público" prestado pelos carteiros que acompanha a execução de suas tarefas. $\mathrm{O}$ cuidado com os objetos postais e a responsabilidade em entregá-los corretamente aparece como um valor compartilhado pela categoria.

O trabalho de distribuição postal é também o momento em que a relação de serviço se manifesta. O contato com a população e os clientes é permanente, permitindo que haja, apesar dos pontos de distribuição rotineiros, uma inconstância nas interações sociais. Com isso, a imagem social do carteiro torna-se um elemento que interfere no relacionamento com a clientela.

Foi possível constatar pelas entrevistas que a imagem dos carteiros, apesar de reiteradas pesquisas de opinião que atestam a confiança da população na categoria profissional, possui uma representação diferenciada. Assim, carteiros que trabalham em áreas economicamente valorizadas me relataram casos de discriminação por parte dos clientes. Nesse sentido, um carteiro deu o seguinte depoimento:

Eu estava na C.C [nome da rua] para fazer a entrega na 'loja X' [fala o nome da loja] e as atendentes não abriram a porta. Mandaram eu jogar pela greta. 
Eu já estava acostumado com isso... tem loja que simplesmente não abre a porta e manda você jogar a carta debaixo da porta... então um rapaz, vestido com camisa do curso de 'inglês Y' [fala o nome para atribuir status de classe média ao sujeito], que estava passando, vira pra mim e fala: 'Que absurdo! Não abrem nem a porta para receber as correspondências!'. Na hora, saí rindo e fui para a próxima loja. Chegando lá, a única funcionária negra, com aquelas roupinhas de empregada, fez também sinal para eu passar as cartas por debaixo da porta. O cara, que ainda estava vendo, ficou rindo e chocado com a situação! (MARCOS, nov. 2011, carteiro)

Outros carteiros me relataram situações semelhantes em bairros considerados nobres. Problemas na entrega de objetos ao destinatário costumam repercutir na relação de serviço entre o carteiro e o cliente:

Eu estava com um talão de cheques MP [significa que só o destinatário pode receber] pra entregar para o dono do restaurante. Só que o nome dele não estava lá no endereço, só o nome da mulher dele e do gerente. Como eles não estavam lá, o dono do restaurante quase me bateu porque eu não entreguei pra ele assinar. Perguntou se eu sabia quem ele era, se eu estava maluco, que ia ligar pro meu chefe... não entreguei! No mês seguinte estava lá o nome dele, mas ele nem quis me receber. Mandou o gerente... (ALESSANDRO, mar. 2010, carteiro)

Ouvi depoimentos semelhantes em outras entrevistas e conversas com carteiros, que evidenciam a representação de classe de alguns moradores e trabalhadores em bairros economicamente valorizados. Mesmo não se tratando de moradores ou proprietários, atendentes de lojas e prestadores de serviços também tendem a relacionar-se com os carteiros como sujeitos de classes sociais subalternas e, por isso, indignos de um tratamento com urbanidade. Essa imagem se distancia, portanto, da ideia tradicional do "carteiro amigo" e querido socialmente. Evidencia, também, uma contradição com as pesquisas de opinião que mostram ser uma categoria profissional valorizada pela população.

Ao mesmo tempo, em distritos onde há uma proximidade de classe entre os moradores e os carteiros, encontra-se uma imagem positiva e favorável aos trabalhadores, segundo os carteiros. Isso aparece na imagem de "funcionários públicos", com "bons salários" e "estabilidade", e mesmo em um relacionamento interpessoal mais cortês, com alguns moradores 
considerando o carteiro do distrito como o "meu carteiro". Nesse sentido, há clientes que ligam para os centros de distribuição para solicitar o retorno de um carteiro titular quando ele é substituído, mesmo nas férias. Assim, o trabalho externo do carteiro, além dos aspectos da tarefa em si, é mediado pelas representações sociais de classe, o que interfere no desempenho de suas atividades.

Destaca-se ainda como elemento que interfere no trabalho de distribuição, sobretudo para intensificar o trabalho, a lógica do trabalho por tarefa que advém do método taylorista de gestão. A lógica de tarefa no taylorismo deriva do princípio de separação entre execução e concepção, cabendo aos gerentes prescreverem as tarefas de cada trabalhador, pois, como afirmou Taylor: "A administração científica, em grande parte, consiste em preparar e fazer executar tarefas." (TAYLOR, 1989, p. 53) Dessa forma, o controle da produtividade do trabalho poderia ser medida de acordo a realização do que havia sido prescrito. Assim, além da jornada de trabalho computada em horas, o funcionário também deveria realizar as tarefas estipuladas pelos supervisores.

Nos Correios, o contrato de trabalho do carteiro prevê 44 horas de trabalho por semana, o que se concretizaria com oito horas diárias de trabalho durante a semana e quatro horas aos sábados. No entanto, mediante acordo coletivo, são computadas 40 horas de trabalho de segunda a sexta-feira, ficando o dia de sábado para uma escala especial remunerada.

Em outras palavras, os funcionários que trabalham aos sábados nos serviços internos da empresa - tratamento de objetos -, ou no serviço externo de distribuição de encomendas expressas, recebem quatro horas extras e um adicional de 15\% sobre o salário para quem trabalha todos os sábados. Assim, o contrato de trabalho vigente nos Correios respalda-se na semana de 40 horas de trabalho, embora haja a possibilidade de convocação dos trabalhadores para realização de jornadas extraordinárias aos sábados, como previsto em acordo coletivo.

O conjunto de atividades de trabalho do carteiro é orientado pela lógica da tarefa. Isso implica que, apesar de haver uma jornada de trabalho de 8 horas, os carteiros trabalham pelo regime de tarefas: a jornada de trabalho se encerra quando voltam da distribuição e prestam conta dos objetos 
especiais. Pode ser, no entanto, que o carteiro utilize menos horas para realizar todas as atividades, conseguindo realizá-las em 6 ou 7 horas. Nesses casos, mesmo não tendo cumprido o expediente integralmente, o carteiro está liberado, já que cumpriu sua tarefa. A possibilidade de executar a tarefa diária em menos tempo propicia uma intensificação do trabalho por parte dos carteiros com o aumento da sua cadência.

Assim, torna-se possível que os carteiros terminem suas tarefas, em alguns dias, com menos horas de trabalho, mas também pode ser necessário despender mais horas para executar a mesma tarefa. Isso acontece porque a quantidade de objetos que são destinados para um distrito não é sempre a mesma, apesar de haver uma média para as regiões. Apesar da média, portanto, a carga postal pode oscilar a cada dia. Assim, em busca do término rápido da tarefa, os carteiros trabalham em um ritmo mais acelerado, o que resulta, em alguns casos, em maior produtividade.

Durante as observações nos CDDs, verificou-se que o trabalho por tarefa é controverso entre os carteiros. Se há os que defendem esse regime de trabalho por conseguirem terminar as atividades antes das 8 horas de trabalho, outros alegam que a tarefa só interessa diretamente à empresa, porque muitos deixam de cumprir até mesmo o intervalo para almoço para adiantar as atividades, mesmo que não consigam realizar a tarefa dentro das 8 horas, fazendo com que trabalhem ainda mais.

Diante disso, um impasse se estabelece entre os carteiros, dividindo-os: uns acreditam que são beneficiados com a tarefa diária, já que nos dias em que a quantidade de objetos postais é menor conseguem terminar a tarefa antes do fim do expediente; outros acreditam que é uma forma de organizar a produção que desfavorece os carteiros, já que nos dias em que há uma maior quantidade de objetos postais eles ficam sobrecarregados, precisando trabalhar em um ritmo intenso e com horas extraordinárias para cumprir a tarefa.

Ao retornar da distribuição postal, o carteiro deve informar no sistema informatizado (SGDO) o horário de sua chegada e iniciar as atividades finais de trabalho, como devolver os objetos postais que não puderam ser entregues aos destinatários com o respectivo motivo, como uma possível mudança do destinatário, sua ausência, um número informado 
incorretamente etc. Quando finalizada essa atividade, o carteiro terá cumprido sua tarefa de trabalho e estará liberado. Caso já tenha ultrapassado sua jornada de trabalho, o carteiro fará horas extraordinárias para cumprir a sua tarefa, já que no dia seguinte as mesmas atividades de trabalho recomeçam.

\section{A produção industrial de serviços postais e o caráter conflitivo da organização do trabalho}

A compreensão das relações de trabalho nos Correios requer a retomada de elementos conceituais acerca dos métodos de gestão. Para se discutir como se configuram as relações sociais e de trabalho e os métodos de gestão na ECT, deve-se considerar a lógica da produção industrial de serviço. Essa lógica é acionada quando um cliente vai à agência postar objetos postais. Nesse instante, ao contratar os serviços da empresa, uma relação de serviço é estabelecida. (GADREY, 2001) Ou seja, o cliente da ECT, ao contratar os serviços da empresa, interage no balcão da agência com o atendente comercial. Nesse instante, o objetivo do cliente é que o seu objeto postal seja encaminhado ao local de destino seguindo os prazos que são estipulados e informados nessa relação de serviço.

Os prazos para a entrega dos objetos postais são acordados conforme a modalidade de serviço e os diferentes percursos logísticos que viabilizam o seu cumprimento. Assim, caso um cliente tenha pressa, ele pode contratar o serviço de Sedex, que promete a entrega do objeto postal no dia seguinte ao da postagem, conforme disponibilidade operacional dos Correios na cidade de destino. A ECT denomina esse prazo de D+1, isto é, a data da postagem do objeto mais o dia útil seguinte para a entrega. Assim como nesse exemplo, há diversas modalidades de serviços e prazos, como o Sedex 10, que além de prometer seguir o D+1, garante que a entrega ocorrerá até as 10 horas. E assim é para todos os serviços postais da empresa, que funcionam com prazos estabelecidos e acordados com os clientes na relação de serviço estabelecida na agência.

Para que os prazos sejam cumpridos, os objetos postais seguem em direção aos Centros de Tratamento de Cartas e Objetos Postais (CTCEs), 
onde são separados, triados e encaminhados aos CDDs. Para isso, toda a logística da empresa é acionada, incluindo o transporte por via aérea ou terrestre. Quando os objetos postais chegam aos CDDs, os prazos para entrega estão próximos de findar. Em razão disso, a ECT trabalha, em situações consideradas "normais", sem o acúmulo de objetos postais em suas unidades operacionais.

A lógica que a empresa supostamente segue é a do just in time, já que a demanda por seus serviços postais iniciada na agência aciona toda a cadeia produtiva. A lógica do just in time exigiria que todos os setores operacionais da empresa trabalhassem de forma a não acumular objetos postais em suas unidades operacionais para que todos os prazos estipulados e contratados pelos clientes fossem cumpridos, conforme prevê o modelo toyotista aplicado em atividades terciárias (ZARIFIAN, 2001), o que demanda absoluto controle do processo de trabalho.

No entanto, tal como Zarifian (2001) indica, as empresas que trabalham dentro da lógica de uma produção industrial de serviço comumente não trabalham sob o princípio do just in time, que pressupõe a não formação de estoques, mas sob a lógica fordista clássica de "estoque mínimo". Nos Correios, a aplicação da lógica do just in time no fluxo de distribuição de objetos postais impõe o cumprimento dos prazos assumidos com os clientes e, consequentemente, o alcance do "resto zero" nos Centros de Distribuição. Em outras palavras, os objetos postais que chegam ao CDD precisam, necessariamente, ser distribuídos no mesmo dia. Essa é a norma. Formar qualquer tipo de "estoque", no caso dos Correios, é atrasar a entrega das correspondências.

Apesar disso, é a lógica do "estoque mínimo" que se encontra no funcionamento das atividades de trabalho na ECT. Isso porque os cálculos de produtividade, principalmente a relação estabelecida pela empresa entre quantidade de funcionários de uma unidade operacional e a média de objetos postais, podem não corresponder à carga real de trabalho. Nesse caso, os funcionários precisam priorizar a distribuição de algumas modalidades de serviços postais, como Sedex, objetos postais expressos etc. Sendo assim, priorizam-se aqueles objetos com prazo menor de entrega, fato que deixa algum "resto" a distribuir para o dia seguinte, tanto nos 
CDDs quanto nos Centros de Tratamento de Cartas e Encomendas. Assim, a lógica do "estoque mínimo" - acúmulo de correspondências não entregues - se sobrepõe a do just in time - "resto zero".

Nos CDDs, quando os objetos postais chegam para as atividades de trabalho, exige-se que os carteiros distribuam todos os objetos postais do dia, mesmo que para isso necessitem aumentar a produtividade, ou seja, a velocidade de triagem. Com isso, tal como constatou Zarifian (2001) sobre a utilização do just in time em atividades terciárias, verifica-se também nos Correios a intensificação do trabalho em decorrência da meta de "resto zero". O controle do "resto" de objetos postais é importante para a empresa, de tal forma que no sistema eletrônico de monitoramento das atividades de cada carteiro - SGDO - há um campo específico para informar qual foi o resto do carteiro/distrito no dia. A soma de todos esses "restos" de correspondências dará o quantitativo de todo o CDD.

Diante da intensificação do trabalho na triagem e na distribuição dos objetos postais, uma lógica temporal na realização das atividades é acionada e passa a orientar as ações dos carteiros desde o processo de triagem até a distribuição das correspondências. Esse aspecto leva a uma fragmentação e individualização das atividades de trabalho não só no CDD, mas também em outras áreas operacionais da ECT, fato também analisado por Junquilho e Silva (2004), que colocam a questão - constatada em pesquisa realizada também nos Correios - nos seguintes termos:

[...] há muitas dificuldades para a colaboração e solidariedade nos ambientes de trabalho da XYZ [Diretoria da ECT onde realizaram a pesquisa], sendo importantes causas para tanto a pressão e a noção de tempo e do cumprimento de prazos, prejudicando o ato de dar atenção a terceiros. $\mathrm{Na}$ área operacional, principalmente, é citado o regime de 'tarefas' como um dos responsáveis pela idéia de cada um executar o que lhe é cobrado, ansioso por cumprir uma determinada quantidade de trabalho [...]. (JUNQUILHO; SILVA, 2004, p. 144)

A falta de solidariedade e cooperação que os autores apontam como características das relações sociais entre os funcionários da ECT são decorrentes da pressão para intensificação do trabalho e da noção de tempo escasso e para cumprimento dos prazos. Essas características vivenciadas 
e percebidas pelos funcionários da área operacional apresentam sua origem na organização do trabalho.

A noção de tempo escasso que os carteiros apresentam decorre da lógica do "resto zero", aspecto que pode ser compreendido a partir dos discursos dos trabalhadores que relatam uma disputa em decorrência da intensificação das atividades de trabalho, acirrando o caráter conflitivo das relações entre eles:

Há colegas que incitam a competitividade entre as equipes de trabalho com agressões camufladas de brincadeiras do tipo: 'somos elite e temos que acabar a triagem mais rápido que eles', ou 'nessa equipe aí só tem distrito de moça, porque vocês acabam todos cedo.'(ROBSON, abr. 2010, carteiro)

São os ditos 'amigos' que não podem ver um colega faltar por estar doente que já fazem acusações de preguiça ou que ficam procurando móveis [mesas de triagem] com notas pra colocar [na mesa do carteiro que faltou] para acusar o colega de incompetente. Já vi até gente dizendo que uma carteira devia ter tomado punição por ter reclamado de como a triagem tinha erros demais [de direcionamento das correspondências, o que aumenta o tempo de triagem por dupla separação dos objetos]. (FRED, abr. 2010, carteiro)

Como se observa, os procedimentos de gestão - principalmente a necessidade de intensificar a velocidade de triagem em razão da noção de tempo que perpassa o processo de trabalho - acirram o conflito entre os carteiros, que estabelecem uma vigilância mútua para que atinjam os mesmos índices e terminem o processo de triagem ao mesmo tempo, e não em momentos diferenciados, como permite cada subsetor (cada lado do "U" no layout).

Sendo assim, a norma, o padrão e o índice de triagem ensejam a instauração de uma disputa entre os próprios carteiros envolvidos no processo de trabalho, colocando o foco dos conflitos nas atividades de trabalho de cada funcionário e não nos métodos de gestão. Aliás, aspecto que o toyotismo preconiza por meio da organização do layout, que deve ensejar a visibilidade e exposição dos trabalhadores entre si e perante os gestores.

Essas características das atividades de trabalho e das relações de trabalho, ao se associarem à lógica do trabalho por tarefa, pressionam cada 
um dos funcionários para que realizem suas atividades de maneira fragmentada e individualizada. Como a distribuição postal depende unicamente de cada carteiro no distrito, cada um desses funcionários do CDD exerce suas atividades de forma intensa e individualizada, com o objetivo de terminar sua tarefa no menor prazo a fim de ser liberado mais cedo ou apenas para não cumprir horas extraordinárias.

Um caso emblemático observado relaciona-se com os carteiros motoristas que realizam a entrega dos depósitos. Um dos motoristas responsáveis pela entrega dos depósitos em um dos CDDs estudado, já acostumado a essa atividade, era considerado ágil pelos carteiros, pressionando muitos para que terminassem de preparar os depósitos antes do horário de almoço para ele adiantar a distribuição. Em busca de melhores condições de trabalho, como me revelou em conversa, buscou transferência para o Centro de Encomendas Expressas, porque lá, segundo ele, não há o regime de tarefas e menos pressão durante a jornada de trabalho, além de não necessitar de horas extraordinárias diariamente.

O carteiro escolhido para substituí-lo, selecionado entre os próprios colegas de trabalho, era considerado menos ágil pelos carteiros porque os depósitos estavam sendo entregues com muito atraso. Muitos falaram em espera na rua por mais de uma hora. Em razão das constantes reclamações, houve uma sucessão de intrigas. Segundo o motorista, que foi afastado da função, ele "sabia que queriam" lhe "passar a perna". A resposta oficial para seu afastamento da função foi a sua recusa em realizar novo teste para averiguar sua habilidade ao volante. $\mathrm{O}$ carteiro motorista explicou sua recusa: "não fiz o teste porque já estava motorizado". Pela observação e conversa com carteiros, foi possível verificar que a percepção dos atrasos causados pelo novo motorista era generalizada, razão pela qual pressionaram o gestor do CDD para substituí-lo. Com isso, foi possível acompanhar diversas conversas relacionadas ao caso, com intrigas e conflitos relacionados.

Nesse caso, verifica-se que o trabalho por tarefa pressiona os carteiros para que realizem suas atividades no menor tempo possível, o que inclui a entrega dos depósitos auxiliares em tempo hábil pelos motorizados nos postos indicados, senão o atraso será generalizado, o que impedirá não só o cumprimento dos prazos, mas também demandará de cada carteiro um 
tempo extra de trabalho. Sendo assim, como o trabalho de distribuição é realizado individualmente e de forma fragmentada, sendo cada carteiro responsabilizado pelo seu próprio distrito, a intensificação do trabalho individual demanda, coletivamente, que a maioria dos carteiros realize, num mesmo compasso, as atividades de trabalho. Quando não se segue essa cadência, conflitos e dissensões emergem.

Outros aspectos relacionados à gestão também originam conflitos, como os chamados "gatos" de triagem, ou seja, o direcionamento errado de objetos postais durante a triagem por distritos. Como existe um índice de triagem na distribuição, é preciso triar num compasso constante, o que ocasiona erros no direcionamento de objetos entre distritos. Muitos carteiros durante a Triagem de Distribuição chegaram a solicitar a presença do supervisor de operações junto à mesa de triagem de outro carteiro para averiguar os seus "gatos". Eram constantes as brincadeiras direcionadas nesse sentido: "falta de competência", "carteiro feito nas coxas", "joga carta errado pra mãe", etc. Um dos carteiros, pelas incisivas discussões sobre "gato" com alguns colegas, não conversava com pelo menos outros cinco carteiros.

Os conflitos entre os próprios carteiros durante a jornada de trabalho servem aos gestores como instrumento de controle da insatisfação, porque desviam o foco dos métodos de gestão e das relações de trabalho para os colegas de trabalho - que são responsabilizados pelas condições insatisfatórias. Assim, apesar de haver resistências e conflitos nas relações de trabalho, não são suficientes para arrefecer o caráter conflitivo das relações sociais desencadeado pela produção industrial de serviço postal, propiciando, assim, que a insatisfação e o conflito entre colegas de trabalho sirvam para manutenção do controle gerencial.

Dessa maneira, o caráter conflitivo dessa forma de gerenciamento do trabalho se constitui a partir dos métodos de gestão, que forjam relações sociais conflitivas entre os trabalhadores. No caso dos Correios, o caráter conflitivo da gestão se configura a partir da noção de "tempo escasso" que a lógica do just in time impõe, associado à pressão pela intensificação das atividades de trabalho no CDD para cumprir prazos e atingir o "resto zero", resultando na fragmentação das atividades de trabalho e 
individualização das tarefas, o que incita disputas e conflitos direcionados não à organização do trabalho ou às relações de trabalho, mas aos colegas de profissão.

\section{CONSIDERAÇÕES FINAIS}

Concomitante aos processos de reestruturação organizacional, os processos de trabalho foram reorganizados na ECT entre 1994 e 2011. Ao esquadrinhar a lógica acionada para modernizar o processo de trabalho, verifica-se uma linearidade no período, o que evidencia a continuidade da lógica racionalizadora nas práticas de gestão.

O governo Fernando Henrique Cardoso iniciou o processo de modernização por meio de investimentos na infraestrutura da ECT: ampliou a rede de agências de atendimento, expandiu o número de unidades de triagem e distribuição e, principalmente, investiu em tecnologias da informação e na automação de processos de triagem.

Os investimentos na infraestrutura dos Correios foram realizados com base na lógica industrial, isto é, os administradores da empresa buscaram no setor industrial ferramentas gerenciais para conduzir as operações, aprofundando o modelo de produção industrial de serviço da estatal. As diretrizes para reestruturação das unidades operacionais foram apresentadas no projeto Gestão da Produtividade Aplicada aos Correios (GPAC).

A rede de atendimento foi diretamente impactada por dois aspectos: o avanço da terceirização das agências e a introdução de sistemas informatizados de atendimento. $\mathrm{O}$ primeiro aspecto mostra que as estratégias gerenciais adotadas não só estavam alinhadas com a lógica do capital como também seguiam a tendência internacional no setor. $\mathrm{O}$ segundo aspecto, no entanto, possibilitou à empresa introduzir mecanismos para melhoria da qualidade dos serviços, como o rastreamento de objetos por canais eletrônicos. Apesar disso, os atendentes comerciais mostram que os sistemas adotados nem sempre funcionam adequadamente, gerando insatisfações entre os trabalhadores. Apesar disso, a implantação de uma infraestrutura tecnológica nos Correios e na rede de atendimento foi importante para a modernização de processos de trabalho dos atendentes 
comerciais e mesmo para a melhoria de serviços prestados. Os setores que foram reestruturados e modernizados sob a lógica industrial de maneira incisiva foram os processos intermediários de tratamento e triagem e a distribuição postal.

Em relação aos Centros de Tratamento de Cargas e Encomendas, o intenso processo de automação se destaca. O Programa Corporativo de Automação Industrial da ECT foi responsável pela importação de máquinas que eram responsáveis pela triagem e separação de cerca de $85 \%$ do tráfego postal. Assim, ao seguir uma tendência mundial, inclusive com a adoção das principais tecnologias disponíveis à época, os Correios aumentaram a produtividade e qualidade da triagem.

Como a automação de processos associa-se diretamente a demissões, os operadores de triagem e transbordo ficaram apreensivos com as mudanças e lutaram pela manutenção de seus empregos. Em um contexto em que se discutia a nova Lei Postal, a ECT remanejou os trabalhadores excedentes da triagem manual para outros setores, sobretudo para Centros de Distribuição Domiciliária. Contudo, o quantitativo de operadores de triagem permanece estável desde 2002, indicando que houve a redução da necessidade de trabalhadores na área.

Os Centros de Distribuição Domiciliária, por sua vez, também tiveram a organização do trabalho remodelada a partir do governo de Fernando Henrique Cardoso. Esse processo alinha-se ao que foi analisado no capítulo 2, onde se discutiu como o processo de implantação do taylorismo na década de 1970 na ECT se coaduna com os objetivos e princípios traçados para essa técnica de organização da produção, ou seja, aumentar o controle sobre a organização do trabalho - o técnico e os propósitos sociais coadunados. Essa relação entre a gestão do processo de trabalho e o respeito à hierarquia, à ordem e à disciplina, propiciado pelos princípios tayloristas e fordistas que enfatizam a necessidade de controle da organização do trabalho a fim de aumentar a eficiência e produtividade, fortaleceu a disseminação de práticas racionalizadoras e autoritárias na organização, coadunando-se ao contexto da ditadura militar.

A partir desses mecanismos, portanto, os gestores da ECT iniciaram um processo de estruturação e organização do processo operacional de 
suas unidades visando à melhoria da qualidade dos serviços postais prestados à população, que, segundo os consultores franceses contratados para liderar - juntamente com os gestores da ECT - esse processo, estava aquém de suas possibilidades. Nesse período, portanto, o taylorismo foi o conjunto de princípios e técnicas que estabeleceu as diretrizes para a estruturação e organização do processo de trabalho.

Com a implantação dos princípios tayloristas em Centros de Distribuição Domiciliária para a condução dos processos operacionais, expropriou-se o saber que o carteiro tinha sobre o seu trabalho, submetendo-o ao conjunto de saberes constituídos pelos departamentos responsáveis pela concepção dos processos de trabalho a fim de estabelecer padrões para as atividades de trabalho para todos os funcionários do setor operacional da empresa. Dessa forma, a busca pela produtividade, eficiência e melhoria contínua de serviços postais passou a conduzir as atividades de trabalho e de gestão do processo operacional nos Correios. Os princípios tayloristas, dessa forma, alinhados a técnicas de organização da produção com base no fordismo, propiciaram o enquadramento e o controle dos trabalhadores nessas unidades operacionais.

O principal resultado do projeto GPAC para os Centros de Distribuição Domiciliária foi a reestruturação da organização, originando a Padronização do Processo Produtivo em CDDs. A organização do trabalho, a partir dessa reestruturação, passou a ser orientada pela racionalização do tempo e aumento do controle da qualidade dos processos operacionais e, portanto, pelo maior controle sobre o trabalho.

Assim, a organização do trabalho passou a ser orientada no sentido de evitar o desperdício de tempo e aumentar o controle da qualidade dos processos de separação das correspondências conforme os destinos de distribuição, bem como para a constituição do layout das unidades operacionais e a organização dos trabalhadores visando "otimizar" o seu aproveitamento, isto é, aumentando ainda mais o controle sobre as atividades de trabalho com divisão e prescrição rígidas das tarefas e sobre os processos de produção, já que o aumento das tarefas e a cobrança por produtividade do trabalho somou-se às técnicas tayloristas e fordistas já utilizadas na empresa. 
Diante disso, a ECT passou a apresentar em seu processo de trabalho, portanto, características tayloristas associadas a princípios e métodos do toyotismo, caracterizando, assim, uma hibridização dos modelos produtivos empregados. Essas características, cimentadas por valores sociais embasados na ordem, na rigidez e em princípios de autoridade, manifestaram nos Correios a racionalização e controle dos processos de trabalho de maneira substancial, controlando também os trabalhadores.

O estudo concreto das práticas de gestão das operações na ECT permite corroborar a proposição de Linhart (2007): é preciso analisar como os métodos de gestão da produção são operacionalizados na prática cotidiana das empresas. E isso porque esses métodos são apropriados de maneira específica por cada empresa e por cada setor de atividade. Nos Correios, a reestruturação dos métodos de gestão engendrou um modelo híbrido, com aspectos neofordistas. Para afirmar se tal combinação é possível em outros setores e empresas, somente outras pesquisas específicas poderão revelar.

Nesse sentido, constatou-se que a ECT vem, ao longo dos anos, estruturando e organizando suas atividades operacionais no setor de tratamento e distribuição de objetos postais com base em modelos de gestão tipicamente industriais, como o taylorismo e o toyotismo. A partir da seleção de ferramentas e características desses modelos, a ECT constituiu um modelo híbrido de gestão de suas atividades operacionais.

Esses métodos de gestão, no entanto, ao serem adotados na gestão de serviços e integrados às especificidades do setor postal, como os prazos estabelecidos pela ECT na relação de serviço com seus clientes, propiciam e configuram relações de trabalho marcadas pela cadência acelerada das atividades de trabalho, pela noção de tempo escasso para cumprir os prazos estipulados, aspectos que tornam as atividades de trabalho cada vez mais fragmentadas e individualizadas, já que centradas individualmente em cada funcionário por meio das tarefas delegadas.

Sendo assim, as relações sociais entre os carteiros apresentam-se conflituosas pelas disputas forjadas a partir dos esforços para a realização das atividades de trabalho, bem como por intensas disputas para a conclusão das tarefas de trabalho, elementos que tornam o dissenso e o 
conflito partes integrantes das relações sociais no âmbito das unidades operacionais de distribuição. Tais conflitos nas relações sociais entre os trabalhadores propiciam a reprodução de relações sociais assimétricas na produção, já que as insatisfações são direcionadas não contra as ações gerenciais, mas contra colegas de trabalho, o que favorece o arrefecimento das insatisfações compartilhadas pelos trabalhadores e individualiza as demandas por mudança, com cada trabalhador focando em seu distrito. Conjuntamente, essas imbricações entre as características dos métodos de gestão e das relações sociais no âmbito do trabalho configuram e promovem o caráter conflitivo da gestão.

Esses elementos juntos, mesmo que possibilitem maior produtividade, também implicam, quase sempre, em relações de trabalho que não consideram os sofrimentos e os problemas causados aos trabalhadores.

Importante reiterar que os governos de Fernando Henrique Cardoso, Luís Inácio Lula da Silva e Dilma Rousseff não apresentam uma descontinuidade na lógica adotada no processo de modernização e reestruturação da área operacional, evidenciando como as ferramentas e métodos de gestão se atualizam e cuja suposta neutralidade continua a reproduzir as divisões e interesses de classe. 